\title{
Safety and Effectiveness of Kidney Transplantation Using a Donation-After-Brain-Death Donor With Acute Kidney Injury: A Retrospective Cohort Study
}

Kyeong Deok Kim

Sungkyunkwan University School of Medicine

Kyo Won Lee ( $\nabla$ kw1980.lee@gmail.com)

Sungkyunkwan University School of Medicine

Sang Jin Kim

Sungkyunkwan University School of Medicine

Okjoo Lee

Sungkyunkwan University School of Medicine

Manuel Lim

Sungkyunkwan University School of Medicine

\section{Eun Sung Jeong}

Sungkyunkwan University School of Medicine

Jieun Kwon

Sungkyunkwan University School of Medicine Jaehun Yang

Sungkyunkwan University School of Medicine Jongwook Oh

Sungkyunkwan University School of Medicine Jae Berm Park

Sungkyunkwan University School of Medicine

\section{Research Article}

Keywords: Donation-after-brain-death, Acute kidney injury, Kidney transplantation, Death-censored graft survival, Rabbit anti-thymocyte globulin

Posted Date: November 24th, 2020

DOl: https://doi.org/10.21203/rs.3.rs-107134/v1

License: (c) (1) This work is licensed under a Creative Commons Attribution 4.0 International License. Read Full License 
Version of Record: A version of this preprint was published at Scientific Reports on March 10th, 2021. See the published version at https://doi.org/10.1038/s41598-021-84977-1. 


\section{Abstract}

The use of kidneys from donation-after-brain-death (DBD) donors with acute kidney injury (AKI) is a strategy to expand the donor pool. The aim of this study was to evaluate how kidney transplantation (KT) from a donor with $\mathrm{AKI}$ affects long-term graft survival in various situations. All patients who underwent KT from DBD donors between June 2003 and April 2016 were retrospectively reviewed. The KDIGO (Kidney Disease: Improving Global Outcomes) criteria were used to classify donor AKI. The cohort included 376 donors (no AKI group, $n=117$ [31.1\%]; AKI group $n=259$ [68.9\%]). Death-censored graft survival was similar according to the presence of AKI, AKI severity, and the AKI trend $(p=0.929, p=0.077$, and $p=0.658$, respectively). Patients whose donors had AKI who received using low dose $(1.5 \mathrm{mg} / \mathrm{kg}$ for three days) rabbit anti-thymocyte globulin (r-ATG) as the induction agent had significantly superior deathcensored graft survival compared with patients in that group who received basiliximab $(p=0.039)$. AKI in DBD donors did not affect long-term death-censored graft survival. Low-dose r-ATG may be considered as an induction immunosuppression in recipients receiving kidneys with AKI because it showed better graft survival than basiliximab.

\section{Introduction}

Kidney transplantation is the optimal choice for treating end-stage renal disease (ESRD) because it improves prognosis and quality of life compared with dialysis ${ }^{1}$. However, there is a huge gap between the demand for and supply of donor organs. The Korea Network for Organ Sharing (KONOS) reported that 2,293 patients underwent kidney transplantation (KT) during 2019 in Korea, with one third of the recipients receiving grafts from donation-after-brain-death (DBD) donors; 23,427 patients were still waiting for suitable organs in May $2019^{2}$.

In an attempt to increase the donor pool for kidney transplantation, the American United Network for Organ Sharing suggested the use of expanded criteria donors (ECDs) in 2002, even though those donors have 1.7-fold higher graft failure compared with standard criteria donors (SCDs) ${ }^{3}$. However, some recent studies reported comparable long-term graft survival in recipients who received kidneys from ECDs and SCDs, contrary to expectations ${ }^{4,5}$.

The use of kidneys from DBD donors who experienced acute kidney injury (AKI) at the time of death is another strategy to expand the donor pool ${ }^{6}$. Kwon et al. ${ }^{7}$ reported that delayed graft function (DGF) occurred more often when recipients received a kidney from a donor with AKI than from one without AKI. In addition, the rate of DGF tended to increase with the AKI stage ${ }^{8,9}$. Domagala et al. ${ }^{10}$ reported finding no difference in the rate of biopsy-proven acute rejection (BPAR) episodes between donors with and without AKI in the first year post-transplantation. Those reports thus found no relationship between donors with AKI and graft survival ${ }^{7-10}$. Nonetheless, debate continues regarding the use of donors with AKI. Several studies reported a significant difference in graft survival when using donors with AKI ${ }^{11,12}$. In addition, Yu et al. ${ }^{13}$ reported that the AKI trend is associated with graft survival rather than AKI severity. Park et al. 
reported that DBD donor KT recipients who received kidneys from ECDs with AKI showed worse long-term graft survival than other $\mathrm{KT}$ recipients ${ }^{14}$.

Therefore, in this study, we evaluated the effects of donor AKI on long-term graft survival after KT in various situations. In addition, we compared clinical outcomes, including the DGF rate, estimated glomerular filtration rate (eGFR), and rejection rate.

\section{Results}

\section{Donor and recipient characteristics by donor AKI stage.}

One hundred and seventeen donors $(31.1 \%, 117 / 376)$ were included in the no AKI group, and 259 donors $(68.9 \%, 259 / 376)$ were included in the AKI group. One hundred and two $(27.1 \%, 102 / 376), 71$ (18.9\%, 71/376), and $86(22.9 \%, 86 / 376)$ patients had an AKI classified as KDIGO stage 1, 2, and 3, respectively. The KDIGO stage 3 group included $35(40.7 \%, 35 / 86)$ donors who received renal replacement therapy before procurement. The comparison of donor characteristics according to the presence of AKI and AKI stage is shown in Table 1. The donor's sex and history of DM and HCV did not differ significantly between groups. Donor age was higher in the AKI group $(p=0.025)$; in particular, the stage 1 AKI group had significantly older donors than the other two groups $(p=0.002)$. The history of HTN and proportion of ECDs did not differ significantly between the No AKI and AKI groups. However, donors with stage 1 AKI were more likely than other AKI donors to have HTN and be ECDs $(p=0.018)$. BMI differed significantly between the groups $(p=0.001)$, increasing with AKI stage. A cerebrovascular accident (CVA) caused brain death in the majority of the AKI group $(p=0.013)$, with stage 1 and $2 \mathrm{AKI}$ having a higher proportion of CVA than the other groups $(p=0.011)$. KDRI and KDPI were significantly higher in the AKI group, with stage 1 AKI having significantly higher values than the other groups $(p<0.001)$. In addition, donor creatinine level $(p<0.001)$ was significantly higher in the AKI group $(p<0.001)$, and increased with AKI stage.

Basiliximab was used more in recipients from the No AKI group, and low dose r-ATG was used more in recipients from the AKI group ( $p<0.001)$; in particular, low dose r-ATG was used much more than basiliximab in recipients with stage 3 donors. The combination of tacrolimus, MMF, and MPD was used more in recipients from the AKI group for maintenance immunosuppression $(p=0.006)$ (Table 2$)$.

\section{Death-censored graft survival according to various conditions.}

Donor AKI itself did not affect death-censored graft survival; the 1-, 5-, and 10-year death-censored graft survival rates were $97.4 \%, 89.2 \%$, and $75.1 \%$, respectively, in recipients in the No AKI group and $97.3 \%$, $91.6 \%$, and $76.1 \%$, respectively, in recipients in the AKI group ( $p=0.929)$ (Fig. 1a). This trend was also observed when the AKI group was stratified by KDIGO stage. The KDIGO stage 3 group (the most severe AKI group) did not show the worst graft survival. The 1-, 5-, and 10-year death-censored graft survival rates were similar among the KDIGO groups: Stage 1 (96.0\%, 86.8\%, and 68.8\%), stage 2 (100\%, 93.9\%, and $74.1 \%)$, and stage $3(96.5 \%, 95.1 \%$, and $86.2 \%, p=0.077)$ (Fig. 2a). The AKI trends did not influence 
death-censored graft survival either. The 1-, 5-, and 10-year death-censored graft survival rates were as follows: No AKI $(97.4 \%, 89.2 \%$, and $75.1 \%)$, worsening AKI (97.3\%, 88.7\%, and 73.5\%), and improving AKI $(98.0 \%, 93.0 \%$, and $74.3 \%, p=0.658)$ (Fig. $2 b$ ).

Donor AKI did not have a negative effect on death-censored graft survival in the ECD KT group. The 1and 5-year death-censored graft survival rates in the ECD KT group did not differ significantly between the No AKI (96.4\% and $84.5 \%$ ) and AKI groups (95.1\% and 83.6\%, $p=0.617$ ) (Fig. 3a). AKI also did not negatively affect death-censored graft survival in the high KDPI $(\geq 80)$ group. The 1- and 5-year deathcensored graft survival rates in the high KDPI $(\geq 80)$ group did not differ significantly between the No AKI (95.8\% and $82.1 \%)$ and AKI groups (95.8\% and $83.0 \%, p=0.420)$ (Fig. $3 b$ ).

\section{Other clinical outcomes.}

The DGF rate was significantly higher in recipients with donors in the AKI group $(p<0.001)$ and tended to increase with the AKI stage $(5.1 \%, 17.6 \%, 15.5 \%$, and $61.6 \%$, for the No AKI and stage 1,2 , and 3 AKI groups, respectively $p<0.001$ ) (Table 3 ). However, the DGF rate did not have a negative effect on deathcensored graft survival in the univariate analysis $(p=0.126)($ Table 4$)$.

Nadir SCr within three months post-KT was significantly higher in the AKI group ( $p=0.049)$. However, this value did not differ significantly based on AKI severity $(p=0.265)$. The nadir $\mathrm{SCr}$ seemed to affect deathcensored graft survival in the univariate analysis $(p=0.001)$; however, it was not significant in the multivariate analysis ( $p=0.476$ ) (Table 4). The trend of kidney allograft function, estimated by $\mathrm{SCr}$ and eGFR, was similar between the No AKI and AKI groups ( $p=0.265$ and $p=0.073$, respectively) (Fig. 4).

The rejection rate was similar between the No AKI and AKI groups $(p=0.245)$, but it was significantly higher in the groups with stage 1 and 2 AKI $(p=0.018)$. Acute cellular rejection (ACR) composed a large portion of the rejection cases. Rejection-free graft survival was similar between the No AKI and AKI groups $(p=0.145)$ (Fig. 1b).

\section{Univariate and multivariate risk factors for death-censored graft survival.}

The presence of donor AKI, AKI severity, and the AKI trend were not significant factors associated with death-censored graft survival. In the multivariate analysis, the use of high dose r-ATG as an induction agent, KDRI, and rejection episodes had a negative effect on death-censored graft survival $(p=0.040$, $<.001$, and $<0.001$ ). The use of low dose r-ATG as an induction agent had a positive effect on deathcensored graft survival ( $p=0.003$ ) (Table 4$)$. In addition, the use of high dose r-ATG as an induction agent, KDRI, and rejection episodes had a negative effect in patients with AKI donors $(p=0.025,<0.001$, and 0.002). The use of low dose r-ATG as an induction agent had a positive effect on death-censored graft survival in patients with AKI donors $(p=0.039)$ (Table 5).

\section{Discussion}


In this study, we found that the DGF rate tended to increase with the donor AKI stage. However, AKI in DBD donors did not affect long-term allograft function. The presence of donor AKI, AKI severity, and the AKI trend did not affect death-censored graft survival. In addition, AKI in ECD or high KDPI donors did not change death-censored graft survival. In the AKI group, recipients treated with low dose r-ATG for induction immunosuppression showed better graft survival than patients treated with other types of induction immunosuppression in the multivariate analysis.

Previous studies showed that donors with AKI were associated with a higher rate of $D G F^{7,8,10,15}$, and that the DGF rate was higher with AKIN stage 2 and 3 disease ${ }^{9,16}$. Similarly in our study, the DGF rate tended to increase with the donor AKI stage, especially in stage 3. Although some studies showed that DGF was associated with a greater risk of graft loss ${ }^{17-19}$, DGF did not affect long-term death-censored graft survival in our study. That might have been because we used more r-ATG for induction in the AKI group; previous studies reported that r-ATG could ameliorate ischemic reperfusion injury (IRI) and reduce the incidence of $D G^{20,21}$. DGF is a risk factor for the development of early acute rejection ${ }^{17,22}$. However, previous studies reported that the acute rejection rate was not significantly higher among patients whose donors had AKI than among other $\mathrm{KT}$ recipients $7,8,10,15$. We also observed that donor AKI did not affect the acute rejection rate or rejection-free survival.

Many studies reported that DBD donors with AKI were not associated with graft failure $8-10,15,23,24$, although some studies have shown otherwise ${ }^{11,12}$. Our results show that long-term death-censored graft survival in patients with a DBD donor with AKI was not inferior to that in patients with a DBD donor without AKI. The 10-year death-censored graft survival was $76.1 \%$ in the AKI group and $75.1 \%$ in the No AKI group. In addition, long-term graft function and the eGFR trend were similar between the two groups.

Park et al. ${ }^{14}$ reported that the graft survival of kidneys from ECDs with AKI was significantly worse than that in other groups (ECDs without AKI, SCDs with AKI, and SCDs without AKI). On the other hand, Ko et al. ${ }^{25}$ found no significant difference in the graft survival rate among those four groups. In our cohort, long-term death-censored graft survival was similar between ECDs with and without AKI. Similarly, longterm death-censored graft survival did not differ significantly between high KDPI $(\geq 80)$ donors with and without AKI.

Boffa et al. ${ }^{11}$ reported that the presence and severity of AKI, especially in kidneys from donors with AKIN stage 3 injury, led to inferior graft survival. Yu et al. ${ }^{13}$ reported that the AKI trend, specifically DBD donors with worsening AKI, led to inferior graft survival. However, we found that the AKI trend and severity did not affect death-censored graft survival. On the contrary, although this finding was not statistically significant, graft survival tended to be superior in recipients receiving KDIGO stage 3 kidneys than in recipients receiving KDIGO stage 1 or 2 kidneys. Among the four groups, there was a significant difference in the choice of induction immunosuppressive agents. Compared with the other groups, more recipients receiving KDIGO stage 3 kidneys received low dose r-ATG for induction therapy. We speculate that the difference in induction agents might have affected graft survival. 
In the multivariate analysis, the choice of immunosuppressive induction agent in patients with AKI donors significantly affected death-censored graft survival, which was significantly inferior when using high dose r-ATG as an induction immunosuppressive agent (HR 2.234, $p=0.025)$ and significantly superior when using low dose r-ATG (HR 0.242, $p=0.039)$, even though donor age and the proportions of ECD, KDRI, and KDPI donors were significantly higher in the low dose r-ATG group $(p<0.001)$ (Table S1). Lee et al. ${ }^{26}$ also reported that in patients who received kidneys from deceased donors with AKIN stage 1 or $2 \mathrm{AKI}$, graft survival was better when low dose r-ATG was used as induction therapy, although their finding was not statistically significant. IRI is a major cause of AKI in donors ${ }^{27}$, inducing leukocytes to adhere to the venular endothelium ${ }^{28}$. ATG suppresses immune responses after IRI by causing the apoptosis of T cells in peripheral lymphoid organs ${ }^{29}$, which prevents leukocyte clotting and capillary plugging and helps to preserve the microcirculation of the allograft ${ }^{30}$. Although excessive doses of ATG can worsen allograft survival, adequate doses of ATG appear to have a positive effect on allografts by reducing the consequences of AKI.

In Korea, only $10 \%$ of the patients waiting for suitable organs receive $\mathrm{KT}$, and one third of the donors are DBD donors. Donation of patients deceased due to brain death has reduced since 2016. The proportion of donors of age older than 50 years has increased from $52.1 \%$ in 2014 to $61.5 \%$ in $2019^{2}$. Given the increased proportion of ECDs and high KDPI donors, our finding that donor AKI does not affect graft survival could decrease the number of discarded organs and increase the number of KT recipients.

This study has some limitations. This is a retrospective, single-center cohort study and the period of this cohort is 13 years which is quite long. During this period, selection biases were inevitable due to the evolution of donor selection criteria, changes in the immunosuppression protocol, and the accumulation of experience of clinicians. For this reason, the low dose r-ATG was used later than the high dose r-ATG. Thus, the follow-up period using the low dose r-ATG was shorter and the average age of the donor was higher. Transplanted kidneys with AKI were clinically chosen instead of being discarded. Thus, we might have underestimated the effect of AKI by discarding kidneys due to poor expected outcomes. In addition, the AKI stages might be not correct because we used the KDIGO definition without considering urine output when classifying donor AKI stage.

In conclusion, AKI in DBD donors negatively affected the DGF rate. However, it did not affect long-term graft function or death-censored graft survival. Low dose r-ATG may be considered as an induction immunosuppression in recipients receiving kidneys with AKI because it produced better graft survival than basiliximab.

\section{Materials And Methods}

This retrospective study was approved by the Institutional Review Board of Samsung Medical Center (IRB No. 2020-03-170), and the need for informed consent was waived. All methods were carried out in accordance with relevant guidelines and regulations. 


\section{Patients and data.}

We retrospectively reviewed all patients who underwent KT from DBD donors at Samsung Medical Center in Seoul, Korea, between June 2003 and April 2016. Fig. 5 shows a flow chart summarizing patient enrollment. We included 527 transplants from DBD donors without any cardiac death donors. Primary kidney transplantations and single organ transplantations are included. We excluded patients younger than 18 and those who did not receive immunosuppressive induction therapy, as well as those who received alemtuzumab or a combination of rituximab and rabbit anti-thymocyte globulin (r-ATG). En-bloc transplants, dual kidney transplants, and horseshoe kidney transplants were also excluded. In the end, 376 patients were enrolled in this study.

\section{Immunosuppression.}

The immunosuppressive induction agents used were basiliximab and high and low dose r-ATG. We usually use basiliximab for patients who receive SCD kidneys and r-ATG for patients who receive ECD kidneys. However, we gave induction agents considering individual situations, including immunologic risks and physical conditions. The recipients who received $20 \mathrm{mg}$ of basiliximab as an induction agent were injected intravenously twice on the operative day and on postoperative day 4 . We used high dose rATG (1.5 mg/kg for more than five days) before July 2011 and low dose r-ATG (1.5 mg/kg for three days) after that time. r-ATG was initiated on the operative day and administered daily. $500 \mathrm{mg}$ of intravenous methylprednisolone (MPD) was also used for two days starting on the operative day and tapering as scheduled.

Maintenance immunosuppression was achieved with a triple immunosuppressive regimen consisting of calcineurin inhibitors (CNIs), mycophenolate mofetil (MMF) and MPD. Each patient received MMF and MPD and then either cyclosporine or tacrolimus.

\section{Clinical parameters and outcomes.}

We retrospectively analyzed the donor and recipient data. Donors were compared based on their age; sex; body mass index (BMI) $\left(\mathrm{kg} / \mathrm{m}^{2}\right)$; history of diabetes mellitus (DM), hypertension (HTN), and hepatitis C virus (HCV); cause of death; ECD status; Kidney Donor Risk Index (KDRI); Kidney Donor Profile Index (KDPI); and the initial, peak, and terminal serum creatinine (SCr) according to AKI stage. We calculated the KDRI and KDPI by using the Organ Procurement and Transplantation Network calculator ${ }^{31}$. We received all serial SCr values between the donor's hospitalization and organ procurement from KONOS.

The recipient data collected were age, sex, BMI, cause of ESRD, modality and period of dialysis before KT, percentage of panel-reactive antibodies, number of human leukocyte antigen (HLA) mismatches, induction immunosuppressant type, and maintenance immunosuppression agents.

We used the KDIGO criteria to classify donor AKI stage because a previous report showed that the KDIGO criteria are more useful for predicting DGF in KT recipients than the AKIN (AKI Network) criteria ${ }^{32}$. 
According to the KDIGO criteria, stage 1 is any of the following: increase in SCr by $\geq 0.3 \mathrm{mg} / \mathrm{dL}$ within 48 hours (h), increase in $\mathrm{SCr}$ to $\geq 1.5$ times baseline that is known or presumed to have occurred within 7 days, or a reduction in urine output $(<0.5 \mathrm{~mL} / \mathrm{kg} / \mathrm{h}$ for $6 \mathrm{~h}$ ). Stage 2 is an increase in SCr to 2.0-2.9 times baseline or a reduction in urine output to $<0.5 \mathrm{~mL} / \mathrm{kg} / \mathrm{h}$ for $12 \mathrm{~h}$. Stage 3 is an increase in SCr to 3.0 times baseline or $\geq 4.0 \mathrm{mg} / \mathrm{dL}$ or receipt of renal replacement therapy (RRT); in patients $<18$ years, it is defined as a decrease in eGFR to $<35 \mathrm{ml} / \mathrm{min}$ per $1.73 \mathrm{~m}^{2}$ or a reduction in urine output $(<0.3 \mathrm{~mL} / \mathrm{kg} / \mathrm{h}$ for $24 \mathrm{~h}$ or anuria for $12 \mathrm{~h})^{33}$. We used the KDIGO criteria without urine output because that information was not consistently documented in the records for brain-dead donors from other hospitals. The AKI trend was defined using the differences between the peak and terminal SCr levels during the donor management period. When the terminal SCr was lower than the peak SCr, it was defined as improving AKI, and when the terminal $\mathrm{SCr}$ equaled the peak $\mathrm{SCr}$, it was defined as worsening $\mathrm{AKI}^{13}$. We used the Revised Bedside Schwartz Formula to estimate GFR for patients less than 18 years old and the Modification of Diet in Renal Disease equation to estimate GFR for patients over 18. BPAR was defined and classified according to the Banff 2013 classification.

Kidneys were discarded if they were grossly discolored or atrophied or if the donor's SCr had elevated for more than 7 days without renal replacement therapy.

The primary outcome was the effect of donor AKI, AKI severity, and the AKI trend on death-censored allograft survival, as well as the effect of AKI on death-censored graft survival for KTs using kidneys from ECDs and high KDPI donors. The secondary outcomes were the incidence of DGF, nadir SCr, time to nadir $\mathrm{SCr}$ over 3 months, changes in allograft function based on $\mathrm{Cr}$ and eGFR, and the rejection rate. We also investigated whether graft survival was influenced by the type of induction immunosuppression.

\section{Statistical analyses.}

Continuous variables are presented as means \pm standard deviations and were compared using the student's t-test and one-way analysis of variance or as medians with interquartile ranges, which were compared using the Kruskal-Wallis test. Categorical variables are presented as numbers and percentages and were compared by chi-square tests. Graft failure was defined as restarting dialysis or retransplantation. The trends of postoperative SCr and eGFR were compared using linear mixed models. Graft survival was estimated using the Kaplan-Meier method and compared using the log-rank test. Cox proportional hazards model analyses were used to predict graft survival. The multivariate analysis was performed using the factors from the univariate analysis that were statistically significant $(p<0.05)$ and clinically significant factors that were not statistically significant in the univariate analysis. All tests were two-tailed, and statistical significance was defined as $p<0.05$. All statistical analyses were done using SPSS version 25.0 (SPSS, Inc., IBM Corporation, Armonk, NY, USA).

\section{Abbreviations}

ACR, acute cellular rejection 
AKI, acute kidney injury

AMR, antibody-mediated rejection

$\mathrm{BMI}$, body mass index

BPAR, biopsy-proven acute rejection

DBD, donation after brain death

DGF, delayed graft function

DM, diabetes mellitus

ECD, expanded criteria donor

eGFR, estimated glomerular filtration rate

ESRD, end-stage renal disease

HCV, hepatitis c virus

HLA, human leukocyte antigen

HTN, hypertension

KDIGO, Kidney Disease: Improving Global Outcomes

$\mathrm{KDPI}$, kidney donor profile index

KDRI, kidney donor risk index

KONOS, Korea network for organ sharing

$\mathrm{KT}$, kidney transplantation

MMF, mycophenolate mofetil

MPD, methylprednisolone

r-ATG, rabbit anti-thymocyte globulin

SCD, standard criteria donor

$\mathrm{SCr}$, serum creatinine

\section{Declarations}


Acknowledgements

Not applicable

\section{Author contribution}

K.D.K. and K.W.L. developed the research idea. K.D.K., K.W.L. and J.B.P. participated in the study design and writing of the paper. K.D.K., S.J.K., O.L. and M.L. participated in data acquisition. K.D.K., E.S.J and J.O. participated in statistical analysis. K.D.K., K.W.L., J.K. and J.Y participated in data interpretation. Each author contributed important intellectual content during manuscript drafting. K.W.L. and J.B.P. provided supervision.

\section{Funding}

The authors declare no funding was received for this study.

\section{Competing interest}

The authors declare no competing interest.

\section{Additional information}

Correspondence and requests for materials should be addressed to K.W.L.

\section{References}

1. Wolfe, R. A. et al. Comparison of mortality in all patients on dialysis, patients on dialysis awaiting transplantation, and recipients of a first cadaveric transplant. N. Engl. J. Med.341, 1725-1730 http://doi.org/10.1056/NEJM199912023412303 (1999).

2. Korean Network for Organ Sharing. 2018 Annual data report. http://www.konos.go.kr.

3. Rosengard, B. R. et al. Report of the Crystal City meeting to maximize the use of organs recovered from the cadaver donor. Am. J. Transplant.2, 701-711 http://doi.org/10.1034/j.16006143.2002.20804.x (2002).

4. Ko, K. J. et al. Kidney Transplantation Using Expanded-Criteria Deceased Donors: A Comparison With Ideal Deceased Donors and Non-Expanded-Criteria Deceased Donors. Transplant. Proc.50, 32223227 http://doi.org/10.1016/j.transproceed.2018.05.028 (2018).

5. Hwang, J. K. et al. Long-term outcomes of kidney transplantation from expanded criteria deceased donors at a single center: comparison with standard criteria deceased donors. Transplant. Proc.46, 431-436 http://doi.org/10.1016/j.transproceed.2013.11.061 (2014).

6. van der Windt, D. J. et al. Donor acute kidney injury and its effect on 1-year post-transplant kidney allograft fibrosis. Clin. Transplant.34, e13770 http://doi.org/10.1111/ctr.13770 (2020). 
7. Kwon, J. A. et al. Factors of Acute Kidney Injury Donors Affecting Outcomes of Kidney Transplantation From Deceased Donors. Transplant. Proc.51, 2575-2581

http://doi.org/10.1016/j.transproceed.2019.03.068 (2019).

8. Gwon, J. G., Kim, M. G., Park, K. T., Ko, S. Y. \& Jung, C. W. Clinical Outcomes in Kidney

Transplantation from Deceased Donors with Acute Kidney Injury Based on Acute Kidney Injury Network Criteria. Transplant. Proc.50, 2426-2430 http://doi.org/10.1016/j.transproceed.2018.03.072 (2018).

9. Heilman, R. L. et al. Long-term Outcomes Following Kidney Transplantation From Donors With Acute Kidney Injury. Transplantation103, e263-e272 http://doi.org/10.1097/TP.0000000000002792 (2019).

10. Domagala, P. et al. Successful transplantation of kidneys from deceased donors with terminal acute kidney injury. Ren. Fail.41, 167-174 http://doi.org/10.1080/0886022X.2019.1590209 (2019).

11. Boffa, C. et al. Transplantation of Kidneys From Donors With Acute Kidney Injury: Friend or Foe? Am. J. Transplant.17, 411-419 http://doi.org/10.1111/ajt.13966 (2017).

12. Schutte-Nutgen, K. et al. Expanding the donor pool in kidney transplantation: Should organs with acute kidney injury be accepted?-A retrospective study. PLoS One14, e0213608 http://doi.org/10.1371/journal.pone.0213608 (2019).

13. Yu, M. Y. et al. Trend, not severity, of acute kidney injury affects graft outcome in deceased donor kidney transplantation. Clin. Transplant.32, e13431 http://doi.org/10.1111/ctr.13431 (2018).

14. Park, W. Y. et al. Impact of acute kidney injury in expanded criteria deceased donors on posttransplant clinical outcomes: multicenter cohort study. BMC Nephrol.20, 39 http://doi.org/10.1186/s12882-019-1225-1 (2019).

15. Bauer, J. et al. Success of kidney transplantations from deceased donors with acute kidney injury. Ann. Transplant.23, 836-844 http://doi.org/10.12659/AOT.912660 (2018).

16. Hall, I. E. et al. Associations of deceased donor kidney injury with kidney discard and function after transplantation. Am. J. Transplant.15, 1623-1631 http://doi.org/10.1111/ajt.13144 (2015).

17. Yarlagadda, S. G., Coca, S. G., Formica, R. N., Jr., Poggio, E. D. \& Parikh, C. R. Association between delayed graft function and allograft and patient survival: a systematic review and meta-analysis. Nephrol. Dial. Transplant.24, 1039-1047 http://doi.org/10.1093/ndt/gfn667 (2009).

18. Butala, N. M., Reese, P. P., Doshi, M. D. \& Parikh, C. R. Is delayed graft function causally associated with long-term outcomes after kidney transplantation? Instrumental variable analysis. Transplantation95, 1008-1014 http://doi.org/10.1097/TP.0b013e3182855544 (2013).

19. Gill, J., Dong, J., Rose, C. \& Gill, J. S. The risk of allograft failure and the survival benefit of kidney transplantation are complicated by delayed graft function. Kidney Int.89, 1331-1336 http://doi.org/10.1016/j.kint.2016.01.028 (2016).

20. Noel, C. et al. Daclizumab versus antithymocyte globulin in high-immunological-risk renal transplant recipients. J. Am. Soc. Nephrol.20, 1385-1392 http://doi.org/10.1681/ASN.2008101037 (2009).

21. Guirado, L. Does Rabbit Antithymocyte Globulin (Thymoglobuline(R)) Have a Role in Avoiding Delayed Graft Function in the Modern Era of Kidney Transplantation? J. Transplant.2018, 4524837 
http://doi.org/10.1155/2018/4524837 (2018).

22. Wu, W. K., Famure, O., Li, Y. \& Kim, S. J. Delayed graft function and the risk of acute rejection in the modern era of kidney transplantation. Kidney Int.88, 851-858 http://doi.org/10.1038/ki.2015.190 (2015).

23. Klein, R. et al. Transplantation with kidneys retrieved from deceased donors with acute renal failure. Transplantation95, 611-616 http://doi.org/10.1097/TP.0b013e318279153c (2013).

24. Hall, I. E. et al. Deceased-donor acute kidney injury is not associated with kidney allograft failure. Kidney Int.95, 199-209 http://doi.org/10.1016/j.kint.2018.08.047 (2019).

25. Ko, K. J. et al. Kidney transplantation using expanded criteria deceased donors with terminal acute kidney injury: a single center experience in Korea. Ann. Surg. Treat. Res.95, 278-285 http://doi.org/10.4174/astr.2018.95.5.278 (2018).

26. Lee, C. H., Gwon, J. G. \& Jung, C. W. Effectiveness of Thymoglobulin Induction Therapy in Kidney Transplant From Deceased Donor With Mild to Moderate Acute Kidney Injury. Transplant. Proc.51, 2611-2614 http://doi.org/10.1016/j.transproceed.2019.02.061 (2019).

27. Fung, A., Zhao, H., Yang, B., Lian, Q. \& Ma, D. Ischaemic and inflammatory injury in renal graft from brain death donation: an update review. J. Anesth.30, 307-316 http://doi.org/10.1007/s00540-0152120-y (2016).

28. Granger, D. N., Benoit, J. N., Suzuki, M. \& Grisham, M. B. Leukocyte adherence to venular endothelium during ischemia-reperfusion. Am. J. Physiol.257, G683-688 http://doi.org/10.1152/ajpgi.1989.257.5.G683 (1989).

29. Preville, X. et al. Mechanisms involved in antithymocyte globulin immunosuppressive activity in a nonhuman primate model. Transplantation71, 460-468 http://doi.org/10.1097/00007890200102150-00021 (2001).

30. Chappell, D., Beiras-Fernandez, A., Hammer, C. \& Thein, E. In vivo visualization of the effect of polyclonal antithymocyte globulins on the microcirculation after ischemia/reperfusion in a primate model. Transplantation81, 552-558 http://doi.org/10.1097/01.tp.0000200305.48244.a6 (2006).

31. Organ Procurement and Transplantation Network. A guide to calculating and interpreting KDPI. https://optn.transplant.hrsa.gov/media/1512/guide_to_calculating_interpreting_kdpi.pdf (2019).

32. Kim, J. H. et al. Prediction of clinical outcomes after kidney transplantation from deceased donors with acute kidney injury: a comparison of the KDIGO and AKIN criteria. BMC Nephrol.18, 39 http://doi.org/10.1186/s12882-017-0461-5 (2017).

33. Khwaja, A. KDIGO clinical practice guidelines for acute kidney injury. Nephron Clin. Pract.120, c179184 http://doi.org/10.1159/000339789 (2012).

\section{Tables}

Table 1. Clinical characteristics of donors according to AKI stage. 


\begin{tabular}{|c|c|c|c|c|c|c|c|}
\hline & $\begin{array}{l}\text { No AKI } \\
(\mathrm{n}= \\
117)\end{array}$ & $\begin{array}{l}\text { AKI } \\
(n= \\
259)\end{array}$ & $p$-value & $\begin{array}{l}\text { KDIGO } \\
\text { stage } 1 \\
(n=102)\end{array}$ & $\begin{array}{l}\text { KDIGO } \\
\text { stage } 2 \\
(n=71)\end{array}$ & $\begin{array}{l}\text { KDIGO } \\
\text { stage } 3 \\
(n=86)\end{array}$ & $p$-value \\
\hline Age (years) & $\begin{array}{l}44.2 \pm \\
16.0\end{array}$ & $\begin{array}{l}47.9 \pm \\
14.1\end{array}$ & 0.025 & $\begin{array}{l}51.8 \pm \\
15.5\end{array}$ & $\begin{array}{l}44.5 \pm \\
13.6\end{array}$ & $\begin{array}{l}46.1 \pm \\
11.7\end{array}$ & 0.002 \\
\hline Sex (n, \% male) & $\begin{array}{l}75 \\
(64.1)\end{array}$ & $\begin{array}{l}176 \\
(68.0)\end{array}$ & 0.463 & $63(61.8)$ & 56 (78.9) & 57 (66.3) & 0.101 \\
\hline BMI $\left(\mathrm{kg} / \mathrm{m}^{2}\right)$ & $\begin{array}{l}22.5 \pm \\
3.2\end{array}$ & $\begin{array}{l}23.7 \pm \\
3.4\end{array}$ & 0.002 & $\begin{array}{l}23.3 \pm \\
3.3\end{array}$ & $\begin{array}{l}23.5 \pm \\
3.8\end{array}$ & $24.4 \pm 3.2$ & 0.001 \\
\hline \multicolumn{8}{|l|}{ Cormobidities } \\
\hline $\begin{array}{l}\text { Diabetes mellitus } \\
(n, \%)\end{array}$ & $8(7.0)$ & $\begin{array}{l}31 \\
(12.4)\end{array}$ & 0.124 & $16(16.0)$ & $5(7.6)$ & $10(11.9)$ & 0.147 \\
\hline $\begin{array}{l}\text { Hypertension (n, } \\
\% \text { ) }\end{array}$ & $\begin{array}{l}26 \\
(22.8)\end{array}$ & $\begin{array}{l}65 \\
(26.1)\end{array}$ & 0.501 & $34(34.0)$ & 19 (28.8) & $12(14.5)$ & 0.018 \\
\hline $\operatorname{HCV}(n, \%)$ & $2(1.8)$ & $2(0.8)$ & 0.587 & $0(0)$ & $2(2.8)$ & $0(0)$ & 0.160 \\
\hline $\begin{array}{l}\text { Cause of death (n, } \\
\%)\end{array}$ & & & 0.013 & & & & 0.011 \\
\hline $\begin{array}{l}\text { Cerebrovascular } \\
\text { accident }\end{array}$ & $\begin{array}{l}54 \\
(46.1)\end{array}$ & $\begin{array}{l}130 \\
(50.2)\end{array}$ & & $57(55.9)$ & $37(52.1)$ & 36 (41.9) & \\
\hline Trauma & $\begin{array}{l}43 \\
(36.8)\end{array}$ & $\begin{array}{l}57 \\
(22.0)\end{array}$ & & 18 (17.6) & $17(30.0)$ & $22(25.6)$ & \\
\hline $\begin{array}{l}\text { Hypoxic brain } \\
\text { damage }\end{array}$ & $\begin{array}{l}16 \\
(13.7)\end{array}$ & $\begin{array}{l}60 \\
(23.2)\end{array}$ & & 19 (18.6) & 15 (21.1) & $26(30.2)$ & \\
\hline Other & $4(3.4)$ & $\begin{array}{l}12 \\
(4.6)\end{array}$ & & $8(7.9)$ & $2(2.8)$ & $2(2.3)$ & \\
\hline $\begin{array}{l}\text { Donor's status } \\
(\mathrm{ECD})(\mathrm{n}, \%)\end{array}$ & $\begin{array}{l}28 \\
(23.9)\end{array}$ & $\begin{array}{l}83 \\
(32.0)\end{array}$ & 0.110 & $42(41.2)$ & $16(22.5)$ & $25(29.1)$ & 0.018 \\
\hline $\begin{array}{l}\text { Kidney Donor Risk } \\
\text { Index }\end{array}$ & $\begin{array}{l}1.08 \pm \\
0.41\end{array}$ & $\begin{array}{l}1.26 \pm \\
0.45\end{array}$ & 0.001 & $\begin{array}{l}1.38 \pm \\
0.57\end{array}$ & $\begin{array}{l}1.16 \pm \\
0.34\end{array}$ & $\begin{array}{l}1.18 \pm \\
0.34\end{array}$ & $<0.001$ \\
\hline $\begin{array}{l}\text { Kidney Donor } \\
\text { Profile Index }\end{array}$ & $\begin{array}{l}50.4 \pm \\
27.8\end{array}$ & $\begin{array}{l}63.0 \pm \\
23.9\end{array}$ & $<0.001$ & $\begin{array}{l}67.1 \pm \\
27.0\end{array}$ & $\begin{array}{l}59.4 \pm \\
21.3\end{array}$ & $\begin{array}{l}61.2 \pm \\
21.2\end{array}$ & $<0.001$ \\
\hline \multicolumn{8}{|l|}{$\begin{array}{l}\text { Creatinine level } \\
(\mathrm{mg} / \mathrm{dl})\end{array}$} \\
\hline Initial & $\begin{array}{l}0.99 \pm \\
0.29\end{array}$ & $\begin{array}{l}1.48 \pm \\
1.15\end{array}$ & $<0.001$ & $\begin{array}{l}1.17 \pm \\
0.42\end{array}$ & $\begin{array}{l}1.35 \pm \\
0.75\end{array}$ & $\begin{array}{l}1.95 \pm \\
1.73\end{array}$ & $<0.001$ \\
\hline Peak & $\begin{array}{l}1.06 \pm \\
0.29\end{array}$ & $\begin{array}{l}2.60 \pm \\
1.55\end{array}$ & $<0.001$ & $\begin{array}{l}1.53 \pm \\
0.40\end{array}$ & $\begin{array}{l}2.25 \pm \\
0.78\end{array}$ & $\begin{array}{l}4.12 \pm \\
1.64\end{array}$ & $<0.001$ \\
\hline Terminal & $\begin{array}{l}0.91 \pm \\
0.27\end{array}$ & $\begin{array}{l}2.00 \pm \\
1.21\end{array}$ & $<0.001$ & $\begin{array}{l}1.26 \pm \\
0.43\end{array}$ & $\begin{array}{l}1.72 \pm \\
0.77\end{array}$ & $\begin{array}{l}3.13 \pm \\
1.33\end{array}$ & $<0.001$ \\
\hline
\end{tabular}


Continuous variables given as mean \pm SD.

AKI, acute kidney injury; KDIGO, Kidney Disease: Improving Global Outcomes; BMI, body mass index; HCV, hepatitis c virus; ECD, expanded criteria donor.

Table 2. Clinical characteristics of recipient according to AKI stage. 


\begin{tabular}{|c|c|c|c|c|c|c|c|}
\hline & $\begin{array}{l}\text { No AKI } \\
(n= \\
117)\end{array}$ & $\begin{array}{l}\text { AKI } \\
(n= \\
259)\end{array}$ & $p$-value & $\begin{array}{l}\text { KDIGO } \\
\text { stage } 1 \\
(n= \\
102)\end{array}$ & $\begin{array}{l}\text { KDIGO } \\
\text { stage } 2 \\
(n=71)\end{array}$ & $\begin{array}{l}\text { KDIGO } \\
\text { stage } 3 \\
(n=86)\end{array}$ & $p$-value \\
\hline Age (years) & $\begin{array}{l}46.2 \pm \\
11.9\end{array}$ & $\begin{array}{l}48.2 \pm \\
11.9\end{array}$ & 0.119 & $\begin{array}{l}48.2 \pm \\
10.7\end{array}$ & $\begin{array}{l}47.9 \pm \\
11.3\end{array}$ & $\begin{array}{l}48.3 \pm \\
11.0\end{array}$ & 0.481 \\
\hline Sex (n, \% male) & $\begin{array}{l}63 \\
(53.8)\end{array}$ & $\begin{array}{l}159 \\
(61.4)\end{array}$ & 0.168 & $\begin{array}{l}57 \\
(55.9)\end{array}$ & $\begin{array}{l}50 \\
(70.4)\end{array}$ & $\begin{array}{l}52 \\
(60.5)\end{array}$ & 0.132 \\
\hline BMI $\left(\mathrm{kg} / \mathrm{m}^{2}\right)$ & $\begin{array}{l}23.6 \pm \\
3.5\end{array}$ & $\begin{array}{l}23.2 \pm \\
3.4\end{array}$ & 0.313 & $\begin{array}{l}23.2 \pm \\
3.6\end{array}$ & $\begin{array}{l}22.6 \pm \\
2.9\end{array}$ & $\begin{array}{l}23.8 \pm \\
3.4\end{array}$ & 0.118 \\
\hline \multicolumn{8}{|l|}{ Cormobidities } \\
\hline Diabetes mellitus ( $\mathrm{n}, \%)$ & $\begin{array}{l}24 \\
(20.5)\end{array}$ & $\begin{array}{l}52 \\
(20.1)\end{array}$ & 0.922 & $\begin{array}{l}25 \\
(24.5)\end{array}$ & $9(12.7)$ & $\begin{array}{l}18 \\
(20.9)\end{array}$ & 0.294 \\
\hline Hypertension (n, \%) & $\begin{array}{l}95 \\
(81.2)\end{array}$ & $\begin{array}{l}211 \\
(81.5)\end{array}$ & 0.950 & $\begin{array}{l}82 \\
(80.4)\end{array}$ & $\begin{array}{l}61 \\
(85.9)\end{array}$ & $\begin{array}{l}68 \\
(79.1)\end{array}$ & 0.720 \\
\hline Cause of ESRD $(n, \%)$ & & & 0.739 & & & & 0.524 \\
\hline DM nephropathy & $\begin{array}{l}23 \\
(19.7)\end{array}$ & $\begin{array}{l}46 \\
(17.8)\end{array}$ & & $\begin{array}{l}21 \\
(20.6)\end{array}$ & $9(12.7)$ & $\begin{array}{l}16 \\
(18.6)\end{array}$ & \\
\hline Hypertension & $\begin{array}{l}14 \\
(12.0)\end{array}$ & $\begin{array}{l}42 \\
(16.2)\end{array}$ & & $\begin{array}{l}22 \\
(21.6)\end{array}$ & $\begin{array}{l}10 \\
(14.1)\end{array}$ & $\begin{array}{l}10 \\
(11.6)\end{array}$ & \\
\hline GN & $\begin{array}{l}28 \\
(23.9)\end{array}$ & $\begin{array}{l}64 \\
(24.7)\end{array}$ & & $\begin{array}{l}26 \\
(25.5)\end{array}$ & $\begin{array}{l}16 \\
(22.5)\end{array}$ & $\begin{array}{l}22 \\
(25.6)\end{array}$ & \\
\hline ADPKD & $7(6.0)$ & $\begin{array}{l}10 \\
(3.9)\end{array}$ & & $4(3.9)$ & $3(4.2)$ & $3(3.5)$ & \\
\hline Other & $\begin{array}{l}45 \\
(38.5)\end{array}$ & $\begin{array}{l}97 \\
(37.5)\end{array}$ & & $\begin{array}{l}29 \\
(28.4)\end{array}$ & $\begin{array}{l}33 \\
(46.5)\end{array}$ & $\begin{array}{l}35 \\
(40.7)\end{array}$ & \\
\hline $\begin{array}{l}\text { Modality of dailysis (n, \% } \\
\text { HD) }\end{array}$ & $\begin{array}{l}95 \\
(81.2)\end{array}$ & $\begin{array}{l}202 \\
(78.0)\end{array}$ & 0.371 & $\begin{array}{l}80 \\
(78.4)\end{array}$ & $\begin{array}{l}55 \\
(77.5)\end{array}$ & $\begin{array}{l}67 \\
(77.9)\end{array}$ & 0.685 \\
\hline $\begin{array}{l}\text { Duration of dailysis } \\
\text { (years) }\end{array}$ & $\begin{array}{l}6.2 \pm \\
3.7\end{array}$ & $\begin{array}{l}6.3 \pm \\
3.6\end{array}$ & 0.797 & $\begin{array}{l}5.9 \pm \\
3.5\end{array}$ & $\begin{array}{l}6.5 \pm \\
3.4\end{array}$ & $\begin{array}{l}6.6 \pm \\
3.9\end{array}$ & 0.582 \\
\hline $\mathrm{cPRA} \geq 50 \%(\mathrm{n}, \%)$ & $5(4.4)$ & $\begin{array}{l}17 \\
(6.8)\end{array}$ & 0.375 & $7(7.2)$ & $4(5.9)$ & $6(7.1)$ & 0.818 \\
\hline \multicolumn{8}{|l|}{ HLA mismatch } \\
\hline HLA class I & $\begin{array}{l}1.97 \pm \\
1.34\end{array}$ & $\begin{array}{l}2.28 \pm \\
1.19\end{array}$ & 0.024 & $\begin{array}{l}2.23 \pm \\
1.22\end{array}$ & $\begin{array}{l}2.21 \pm \\
1.30\end{array}$ & $\begin{array}{l}2.40 \pm \\
1.06\end{array}$ & 0.098 \\
\hline HLA class II & $\begin{array}{l}0.86 \pm \\
0.72\end{array}$ & $\begin{array}{l}0.91 \pm \\
0.63\end{array}$ & 0.568 & $\begin{array}{l}0.86 \pm \\
0.68\end{array}$ & $\begin{array}{l}0.82 \pm \\
0.54\end{array}$ & $\begin{array}{l}1.03 \pm \\
0.62\end{array}$ & 0.104 \\
\hline $\begin{array}{l}\text { Donor specific antigen ( } \mathrm{n} \text {, } \\
\% \text { ) }\end{array}$ & $4(3.5)$ & $6(2.5)$ & 0.732 & $3(3.2)$ & $1(1.5)$ & $2(2.4)$ & 0.920 \\
\hline
\end{tabular}




\begin{tabular}{|c|c|c|c|c|c|c|c|}
\hline $\begin{array}{l}\text { Induction } \\
\text { immunosuppression (n, } \\
\% \text { ) }\end{array}$ & & & $<0.001$ & & & & $<0.001$ \\
\hline Basiliximab & $\begin{array}{l}82 \\
(70.1)\end{array}$ & $\begin{array}{l}110 \\
(42.5)\end{array}$ & & $\begin{array}{l}53 \\
(52.0)\end{array}$ & $\begin{array}{l}39 \\
(55.0)\end{array}$ & $\begin{array}{l}18 \\
(20.9)\end{array}$ & \\
\hline High dose r-ATG & $\begin{array}{l}22 \\
(18.8)\end{array}$ & $\begin{array}{l}59 \\
(22.8)\end{array}$ & & $\begin{array}{l}21 \\
(20.5)\end{array}$ & $\begin{array}{l}16 \\
(22.5)\end{array}$ & $\begin{array}{l}22 \\
(25.6)\end{array}$ & \\
\hline Low dose r-ATG & $\begin{array}{l}13 \\
(11.1)\end{array}$ & $\begin{array}{l}90 \\
(34.7)\end{array}$ & & $\begin{array}{l}28 \\
(27.5)\end{array}$ & $\begin{array}{l}16 \\
(22.5)\end{array}$ & $\begin{array}{l}46 \\
(53.5)\end{array}$ & \\
\hline $\begin{array}{l}\text { Maintenance } \\
\text { immunosuppression (n, } \\
\%)\end{array}$ & & & 0.006 & & & & 0.042 \\
\hline $\begin{array}{l}\text { Cyclosporine + MMF + } \\
\text { MPD }\end{array}$ & $\begin{array}{l}22 \\
(18.8)\end{array}$ & $\begin{array}{l}23 \\
(8.9)\end{array}$ & & $9(8.8)$ & $8(11.3)$ & $6(7.0)$ & \\
\hline $\begin{array}{l}\text { Tacrolimus + MMF + } \\
\text { MPD }\end{array}$ & $\begin{array}{l}95 \\
(81.2)\end{array}$ & $\begin{array}{l}236 \\
(91.1)\end{array}$ & & $\begin{array}{l}93 \\
(91.2)\end{array}$ & $\begin{array}{l}63 \\
(88.7)\end{array}$ & $\begin{array}{l}80 \\
(93.0)\end{array}$ & \\
\hline
\end{tabular}

Continuous variables given as mean \pm SD.

AKI, acute kidney injury; KDIGO, Kidney Disease: Improving Global Outcomes; BMI, body mass index; ESRD, end stage renal disease; DM, diabetes mellitus; ADPKD, autosomal dominant polycystic kidney disease; HD, hemodialysis; CPRA, calculated panel reactive antibody; HLA, human leukocyte antigen; ATG, anti-thymocyte globulin; MMF, mycophenolate mofetil; MPD, methylprednisolone.

Table 3. Clinical outcomes. 


\begin{tabular}{|c|c|c|c|c|c|c|c|}
\hline & $\begin{array}{l}\text { No AKI } \\
(\mathrm{n}= \\
117)\end{array}$ & $\begin{array}{l}\text { AKI } \\
(n= \\
259)\end{array}$ & $p$-value & $\begin{array}{l}\text { KDIGO } \\
\text { stage } 1 \\
(n= \\
102)\end{array}$ & $\begin{array}{l}\text { KDIGO } \\
\text { stage } 2 \\
(n=71)\end{array}$ & $\begin{array}{l}\text { KDIGO } \\
\text { stage } 3 \\
(n=86)\end{array}$ & $p$-value \\
\hline DGF $(n, \%)$ & $6(5.1)$ & $\begin{array}{l}82 \\
(31.7)\end{array}$ & $<0.001$ & $\begin{array}{l}18 \\
(17.6)\end{array}$ & $\begin{array}{l}11 \\
(15.5)\end{array}$ & $\begin{array}{l}53 \\
(61.6)\end{array}$ & $<0.001$ \\
\hline Graft failure $(n, \%)$ & $\begin{array}{l}26 \\
(22.2)\end{array}$ & $\begin{array}{l}45 \\
(17.4)\end{array}$ & 0.266 & $\begin{array}{l}24 \\
(23.5)\end{array}$ & $\begin{array}{l}12 \\
(16.9)\end{array}$ & $9(10.5)$ & 0.092 \\
\hline $\begin{array}{l}\text { Nadir SCr }(<3 \\
\text { month) }\end{array}$ & $\begin{array}{l}1.18 \pm \\
0.38\end{array}$ & $\begin{array}{l}1.26 \pm \\
0.38\end{array}$ & 0.049 & $\begin{array}{l}1.26 \pm \\
0.45\end{array}$ & $\begin{array}{l}1.26 \pm \\
0.34\end{array}$ & $\begin{array}{l}1.28 \pm \\
0.33\end{array}$ & 0.265 \\
\hline $\begin{array}{l}\text { Time to nadir SCr } \\
\text { (days) }\end{array}$ & $\begin{array}{l}56.6 \pm \\
25.2\end{array}$ & $\begin{array}{l}57.8 \pm \\
24.9\end{array}$ & 0.661 & $\begin{array}{l}53.5 \pm \\
24.6\end{array}$ & $\begin{array}{l}59.6 \pm \\
25.3\end{array}$ & $\begin{array}{l}61.5 \pm \\
24.6\end{array}$ & 0.160 \\
\hline 2-year SCr & $\begin{array}{l}1.25 \pm \\
0.46\end{array}$ & $\begin{array}{l}1.29 \pm \\
0.38\end{array}$ & 0.417 & $\begin{array}{l}1.30 \pm \\
0.42\end{array}$ & $\begin{array}{l}1.34 \pm \\
0.40\end{array}$ & $\begin{array}{l}1.25 \pm \\
0.32\end{array}$ & 0.511 \\
\hline 4-year SCr & $\begin{array}{l}1.28 \pm \\
0.59\end{array}$ & $\begin{array}{l}1.37 \pm \\
0.62\end{array}$ & 0.205 & $\begin{array}{l}1.43 \pm \\
0.75\end{array}$ & $\begin{array}{l}1.38 \pm \\
0.53\end{array}$ & $\begin{array}{l}1.29 \pm \\
0.53\end{array}$ & 0.313 \\
\hline 6-year SCr & $\begin{array}{l}1.18 \pm \\
0.36\end{array}$ & $\begin{array}{l}1.47 \pm \\
0.79\end{array}$ & $<0.001$ & $\begin{array}{l}1.54 \pm \\
0.96\end{array}$ & $\begin{array}{l}1.58 \pm \\
0.89\end{array}$ & $\begin{array}{l}1.30 \pm \\
0.45\end{array}$ & 0.004 \\
\hline 8-year SCr & $\begin{array}{l}1.16 \pm \\
0.39\end{array}$ & $\begin{array}{l}1.35 \pm \\
0.53\end{array}$ & 0.027 & $\begin{array}{l}1.29 \pm \\
0.49\end{array}$ & $\begin{array}{l}1.40 \pm \\
0.58\end{array}$ & $\begin{array}{l}1.36 \pm \\
0.53\end{array}$ & 0.138 \\
\hline 10-year SCr & $\begin{array}{l}1.20 \pm \\
0.44\end{array}$ & $\begin{array}{l}1.35 \pm \\
0.71\end{array}$ & 0.208 & $\begin{array}{l}1.46 \pm \\
1.00\end{array}$ & $\begin{array}{l}1.26 \pm \\
0.40\end{array}$ & $\begin{array}{l}1.33 \pm \\
0.54\end{array}$ & 0.476 \\
\hline $\begin{array}{l}\text { 2-year eGFR, } \\
\mathrm{mL} / \mathrm{min} / 1.73 \mathrm{~m}^{2}\end{array}$ & $\begin{array}{l}59.9 \pm \\
17.9\end{array}$ & $\begin{array}{l}57.5 \pm \\
16.1\end{array}$ & 0.214 & $\begin{array}{l}56.9 \pm \\
17.2\end{array}$ & $\begin{array}{l}57.3 \pm \\
15.9\end{array}$ & $\begin{array}{l}58.2 \pm \\
15.1\end{array}$ & 0.616 \\
\hline $\begin{array}{l}\text { 4-year eGFR, } \\
\mathrm{mL} / \mathrm{min} / 1.73 \mathrm{~m}^{2}\end{array}$ & $\begin{array}{l}59.3 \pm \\
18.8\end{array}$ & $\begin{array}{l}56.7 \pm \\
19.4\end{array}$ & 0.259 & $\begin{array}{l}54.4 \pm \\
17.9\end{array}$ & $\begin{array}{l}56.9 \pm \\
17.5\end{array}$ & $\begin{array}{l}59.0 \pm \\
22.2\end{array}$ & 0.320 \\
\hline $\begin{array}{l}\text { 6-year eGFR, } \\
\mathrm{mL} / \mathrm{min} / 1.73 \mathrm{~m}^{2}\end{array}$ & $\begin{array}{l}60.5 \pm \\
18.4\end{array}$ & $\begin{array}{l}53.8 \pm \\
20.4\end{array}$ & 0.014 & $\begin{array}{l}52.8 \pm \\
22.5\end{array}$ & $\begin{array}{l}53.1 \pm \\
21.3\end{array}$ & $\begin{array}{l}55.5 \pm \\
17.5\end{array}$ & 0.083 \\
\hline $\begin{array}{l}\text { 8-year eGFR, } \\
\mathrm{mL} / \mathrm{min} / 1.73 \mathrm{~m}^{2}\end{array}$ & $\begin{array}{l}62.7 \pm \\
21.8\end{array}$ & $\begin{array}{l}57.0 \pm \\
21.8\end{array}$ & 0.144 & $\begin{array}{l}58.2 \pm \\
20.2\end{array}$ & $\begin{array}{l}56.9 \pm \\
18.9\end{array}$ & $\begin{array}{l}55.9 \pm \\
26.0\end{array}$ & 0.517 \\
\hline $\begin{array}{l}\text { 10-year eGFR, } \\
\mathrm{mL} / \mathrm{min} / 1.73 \mathrm{~m}^{2}\end{array}$ & $\begin{array}{l}60.8 \pm \\
19.4\end{array}$ & $\begin{array}{l}58.0 \pm \\
20.9\end{array}$ & 0.501 & $\begin{array}{l}57.5 \pm \\
23.6\end{array}$ & $\begin{array}{l}61.3 \pm \\
18.6\end{array}$ & $\begin{array}{l}56.1 \pm \\
20.7\end{array}$ & 0.796 \\
\hline Rejection rate $(n, \%)$ & $\begin{array}{l}37 \\
(31.6)\end{array}$ & $\begin{array}{l}98 \\
(37.8)\end{array}$ & 0.245 & $\begin{array}{l}43 \\
(42.2)\end{array}$ & $\begin{array}{l}33 \\
(46.5)\end{array}$ & $\begin{array}{l}22 \\
(25.6)\end{array}$ & 0.018 \\
\hline ACR & $\begin{array}{l}32 \\
(27.4)\end{array}$ & $\begin{array}{l}92 \\
(35.5)\end{array}$ & 0.119 & $\begin{array}{l}40 \\
(39.2)\end{array}$ & $\begin{array}{l}31 \\
(43.7)\end{array}$ & $\begin{array}{l}21 \\
(24.4)\end{array}$ & 0.019 \\
\hline AMR & $3(2.6)$ & $\begin{array}{l}15 \\
(5.8)\end{array}$ & 0.175 & $4(3.9)$ & $6(8.5)$ & $5(5.8)$ & 0.293 \\
\hline Combined ACR + & $6(5.1)$ & $0(0)$ & 0.001 & $0(0)$ & $0(0)$ & $0(0)$ & 0.004 \\
\hline
\end{tabular}




\section{AMR}

Follow up duration (years)
$8.0[5.3-$

11.0]
6.6

[4.3-

8.7] $5.9[4.1-\quad 7.0[4.9-$

8.2]

9.1]
0.002
$6.8[4.8-$

9.7]

0.003

Continuous variables given as mean \pm SD or as median [P25-P75].

AKI, acute kidney injury; KDIGO, Kidney Disease: Improving Global Outcomes; DGF, delayed graft function; $\mathrm{SCr}$, serum creatinine; eGFR, estimated glomerular filtration rate; ACR, acute cellular rejection; AMR, antibody mediated rejection.

Table 4. Univariate and multivariate analyses of risk factors for graft failure. 


\begin{tabular}{|c|c|c|c|c|}
\hline \multirow[t]{2}{*}{ Variables } & \multicolumn{2}{|l|}{ Univariate } & \multicolumn{2}{|l|}{ Multivariate } \\
\hline & $\mathrm{HR}(95 \% \mathrm{Cl})$ & $p$-value & $\mathrm{HR}(95 \% \mathrm{Cl})$ & $p$-value \\
\hline Recipient age & $1.011(0.988-1.033)$ & 0.348 & $1.010(0.984-1.036)$ & 0.463 \\
\hline Male recipient & $1.406(0.867-2.281)$ & 0.165 & $1.439(0.821-2.521)$ & 0.203 \\
\hline Recipient BMI & $1.016(0.950-1.087)$ & 0.644 & & \\
\hline HLA class I mismatch & $1.048(0.865-1.269)$ & 0.634 & & \\
\hline HLA class II mismatch & $1.127(0.791-1.606)$ & 0.508 & & \\
\hline Male donor & $0.776(0.479-1.258)$ & 0.304 & & \\
\hline Donor BMI & 1.033 (0.965-1.106) & 0.345 & & \\
\hline Terminal serum $\mathrm{Cr}$ & $0.821(0.634-1.065)$ & 0.137 & & \\
\hline KDRI & 3.000 (1.906-4.722) & $<0.001$ & $5.202(2.959-9.145)$ & $<0.001$ \\
\hline KDIGO stage & & 0.088 & & \\
\hline No AKI & 1 (Ref.) & & & \\
\hline Stage 1 & $1.460(0.835-2.553)$ & 0.184 & & \\
\hline Stage 2 & $0.905(0.456-1.797)$ & 0.776 & & \\
\hline Stage 3 & $0.556(0.260-1.188)$ & 0.130 & & \\
\hline AKI & $0.978(0.602-1.589)$ & 0.929 & $0.637(0.371-1.096)$ & 0.103 \\
\hline Trend & & 0.659 & & \\
\hline No AKI & 1 (Ref.) & & & \\
\hline Worsening & $1.234(0.653-2.333)$ & 0.518 & & \\
\hline Improving & $0.919(0.533-1.586)$ & 0.762 & & \\
\hline DGF & $1.522(0.888-2.607)$ & 0.126 & $1.444(0.683-3.052)$ & 0.336 \\
\hline Induction immunosuppression & & 0.012 & & $<0.001$ \\
\hline Basiliximab & 1 (Ref.) & & 1 (Ref.) & \\
\hline High dose r-ATG & $1.813(1.107-2.971)$ & 0.018 & $1.752(1.027-2.988)$ & 0.040 \\
\hline Low dose r-ATG & $0.589(0.244-1.422)$ & 0.239 & $0.187(0.061-0.574)$ & 0.003 \\
\hline $\begin{array}{l}\text { Maintenance } \\
\text { immunosuppression }\end{array}$ & & 0.051 & & 0.097 \\
\hline Cyclosporine + MMF + MPD & 1 (Ref.) & & 1 (Ref.) & \\
\hline Tacrolimus + MMF + MPD & $0.581(0.337-1.002)$ & & $0.600(0.328-1.097)$ & \\
\hline
\end{tabular}




\begin{tabular}{|lllll|}
\hline Nadir serum SCr in 3months & $2.535(1.456-4.415)$ & 0.001 & $1.272(0.657-2.464)$ & 0.476 \\
\hline Time to nadir serum SCr & $1.003(0.993-1.013)$ & 0.551 & & \\
\hline Rejection episode & $2.303(1.437-3.688)$ & 0.001 & $3.016(1.801-5.051)$ & $<0.001$ \\
\hline
\end{tabular}

BMI, body mass index; HLA, human leukocyte antigen; $\mathrm{Cr}$, creatinine; KDIGO, Kidney Disease: Improving Global Outcomes; AKI, acute kidney injury; DGF, delayed graft function; ATG, anti-thymocyte globulin; MMF, mycophenolate mofetil; MPD, methylprednisolone.

Table 5. Univariate and multivariate analyses of risk factors for graft failure in patients with AKI donors. 


\begin{tabular}{|c|c|c|c|c|}
\hline \multirow[t]{2}{*}{ Variables } & \multicolumn{2}{|l|}{ Univariate } & \multicolumn{2}{|l|}{ Multivariate } \\
\hline & $\mathrm{HR}(95 \% \mathrm{Cl})$ & $p$-value & $\mathrm{HR}(95 \% \mathrm{Cl})$ & $p$-value \\
\hline Recipient age & $1.008(0.978-1.038)$ & 0.614 & $1.019(0.983-1.056)$ & 0.305 \\
\hline Male recipient & $1.180(0.641-2.174)$ & 0.595 & $0.973(0.424-2.233)$ & 0.949 \\
\hline Recipient BMI & $1.035(0.954-1.122)$ & 0.410 & & \\
\hline HLA class I mismatch & $0.981(0.767-1.256)$ & 0.881 & & \\
\hline HLA class II mismatch & $1.132(0.708-1.808)$ & 0.605 & & \\
\hline Male donor & $0.903(0.485-1.679)$ & 0.746 & & \\
\hline Donor BMI & $1.011(0.929-1.100)$ & 0.795 & & \\
\hline Terminal serum $\mathrm{Cr}$ & $0.787(0.564-1.043)$ & 0.091 & & \\
\hline KDRI & $2.737(1.549-4.835)$ & 0.001 & $4.247(1.934-9.325)$ & $<0.001$ \\
\hline Trend & & 0.353 & & 0.988 \\
\hline Worsening & 1 (Ref.) & & 1 (Ref.) & \\
\hline Improving & $0.740(0.392-1.398)$ & & $0.995(0.478-2.068)$ & \\
\hline DGF & $1.183(0.628-2.227)$ & 0.602 & & \\
\hline Induction immunosuppression & & 0.013 & & 0.001 \\
\hline Basiliximab & 1 (Ref.) & & 1 (Ref.) & \\
\hline High dose r-ATG & $2.062(1.097-3.878)$ & 0.025 & $2.234(1.108-4.503)$ & 0.025 \\
\hline Low dose r-ATG & $0.600(0.219-1.650)$ & 0.323 & $0.242(0.063-0.932)$ & 0.039 \\
\hline $\begin{array}{l}\text { Maintenance } \\
\text { immunosuppression }\end{array}$ & & 0.117 & & 0.381 \\
\hline Cyclosporine + MMF + MPD & 1 (Ref.) & & 1 (Ref.) & \\
\hline Tacrolimus + MMF + MPD & $0.563(0.275-1.154)$ & & $0.692(0.304-1.576)$ & \\
\hline Nadir serum SCr in 3months & $2.535(1.456-4.415)$ & 0.062 & $1.627(0.654-4.050)$ & 0.295 \\
\hline Time to nadir serum SCr & $1.008(0.995-1.021)$ & 0.224 & & \\
\hline Rejection episode & $1.874(1.040-3.375)$ & 0.036 & $2.976(1.506-5.881)$ & 0.002 \\
\hline
\end{tabular}

BMI, body mass index; HLA, human leukocyte antigen; $\mathrm{Cr}$, creatinine; DGF, delayed graft function; ATG, anti-thymocyte globulin; MMF, mycophenolate mofetil; MPD, methylprednisolone. 
a

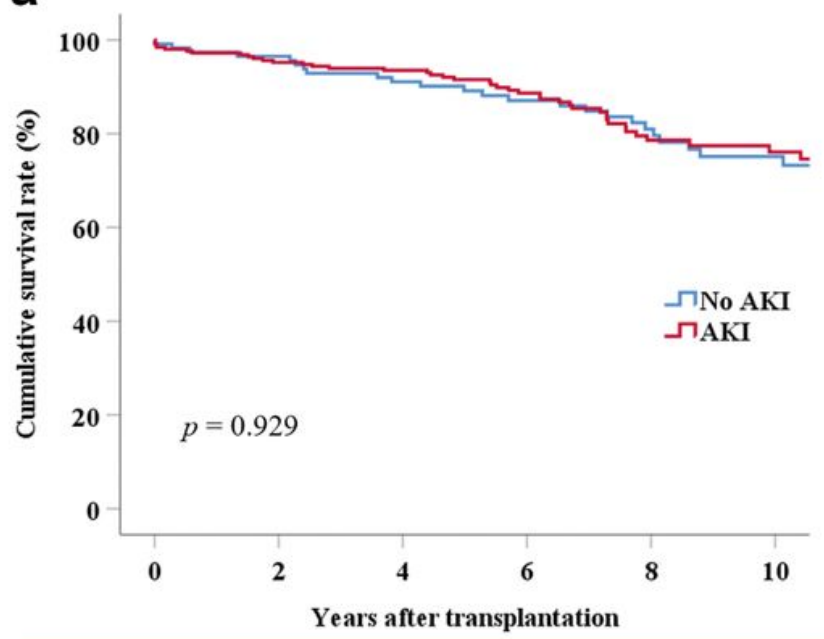

Number at risk

\begin{tabular}{l|l} 
No AKI 117 \\
\hline
\end{tabular}

AKI

(1)

117
259

107

231

\begin{tabular}{|l|}
\hline 98 \\
\hline 210 \\
\hline
\end{tabular}

\begin{tabular}{|l|l|l|}
\hline 81 & 59 & 41 \\
\hline 143 & 84 & 55 \\
\hline
\end{tabular}

\section{Figure 1}

Death-censored and rejection-free graft survival between the No AKI and AKI groups. (a) Death-censored graft survival between the No AKI and AKI groups. Group comparisons were performed using the KaplanMeier and log-rank tests. (b) Rejection-free graft survival between the No AKI and AKI groups. Group comparisons were performed using the Kaplan-Meier and log-rank tests. AKI, acute kidney injury.

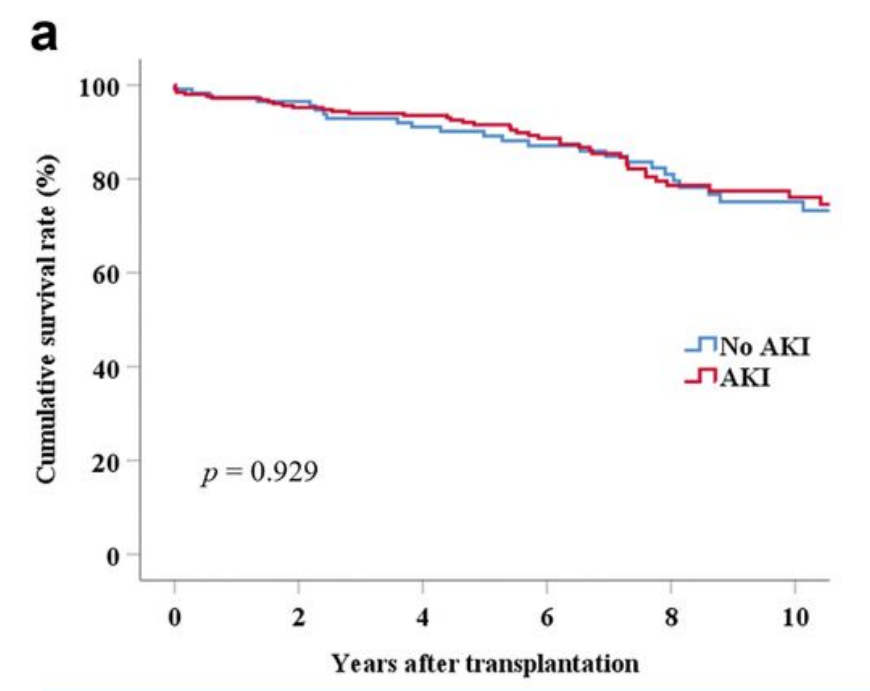

\section{Number at risk}

No AKI 117

AKI 259

98

210

\begin{tabular}{|l|l|l|}
\hline 81 & 59 & 41 \\
\hline 143 & 84 & 55 \\
\hline
\end{tabular}

107

231 b

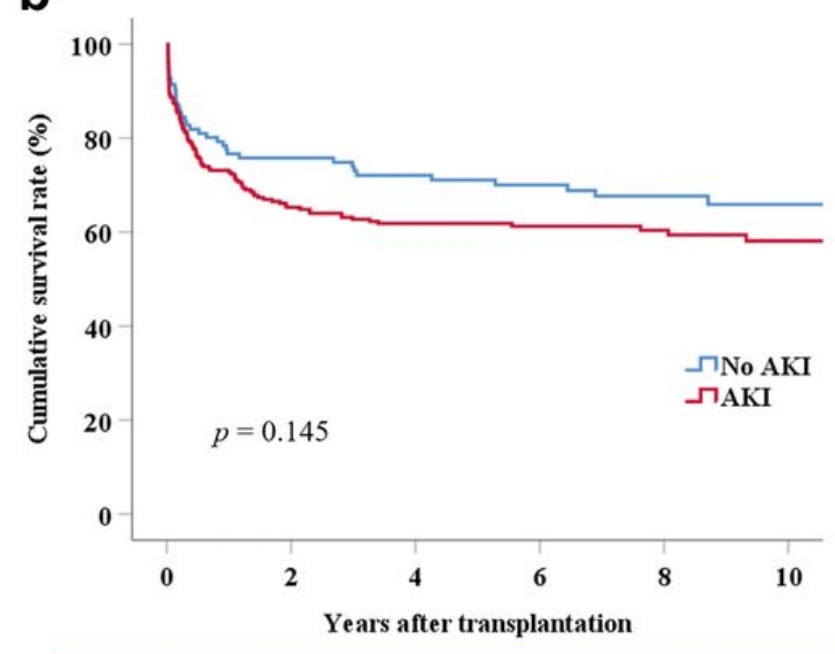

\begin{tabular}{|l|l|l|l|l|l|l|}
\hline \multicolumn{2}{|c|}{ Number at risk } \\
\hline No AKI & 117 & 84 & 74 & 63 & 44 & 31 \\
\hline AKI & 259 & 155 & 137 & 97 & 64 & 41 \\
\hline
\end{tabular}

\section{Figure 1}

Death-censored and rejection-free graft survival between the No AKI and AKI groups. (a) Death-censored graft survival between the No AKI and AKI groups. Group comparisons were performed using the Kaplan- 
Meier and log-rank tests. (b) Rejection-free graft survival between the No AKI and AKI groups. Group comparisons were performed using the Kaplan-Meier and log-rank tests. AKI, acute kidney injury.

a

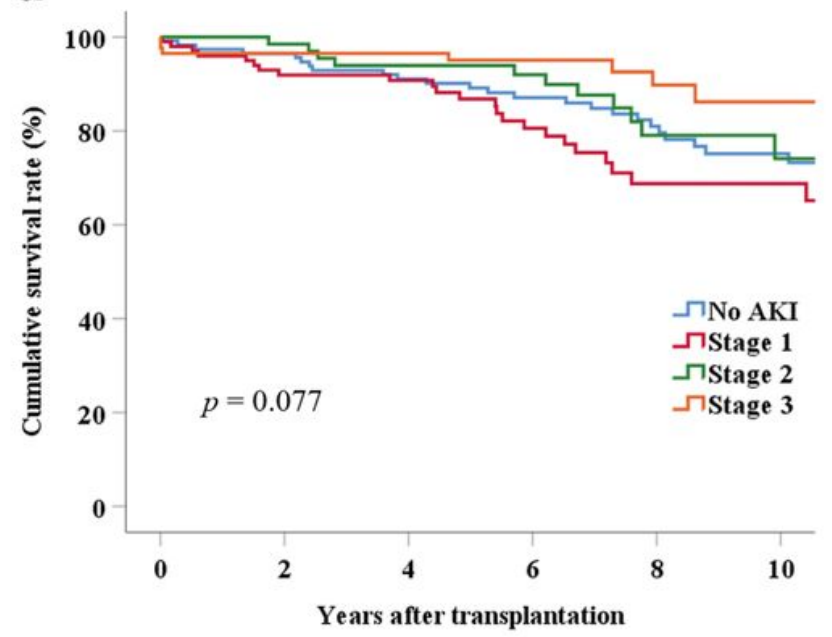

\begin{tabular}{|c|c|c|c|c|c|c|}
\hline \multicolumn{7}{|c|}{ Number at risk } \\
\hline No AKI & 117 & 107 & 98 & 81 & 59 & 41 \\
\hline Stage 1 & 102 & 88 & 78 & 49 & 27 & 19 \\
\hline Stage 2 & 71 & 66 & 60 & 45 & 25 & 15 \\
\hline Stage 3 & 86 & 77 & 72 & 49 & 32 & 21 \\
\hline
\end{tabular}

b

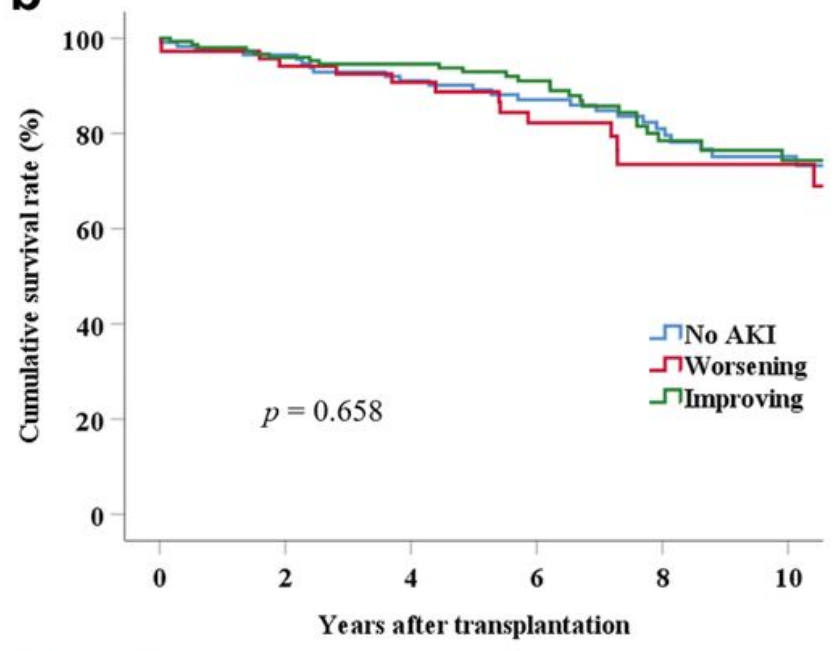

Number at risk

\begin{tabular}{|l|l|l|l|l|l|l|}
\hline No AKI & 117 & 107 & 98 & 81 & 59 & 41 \\
\hline Worsening & 73 & 60 & 49 & 37 & 25 & 16 \\
\hline Improving & 151 & 140 & 131 & 92 & 49 & 34 \\
\hline
\end{tabular}

Figure 2

Death-censored graft survival stratified by AKI severity and trend. (a) Death-censored graft survival stratified by AKI severity. Group comparisons were performed using the Kaplan-Meier and log-rank tests.

(b) Death-censored graft survival stratified by the AKI trend. Group comparisons were performed using the Kaplan-Meier and log-rank tests.

a

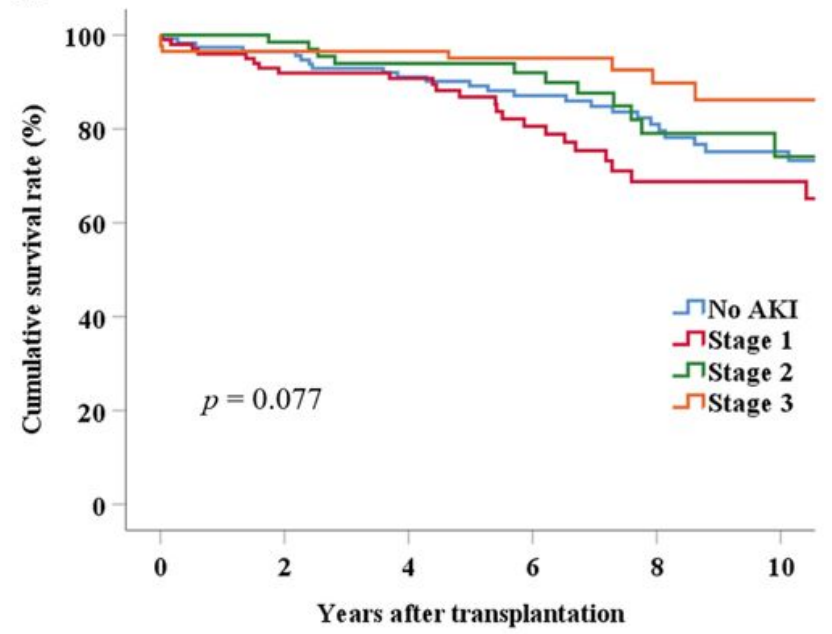

\section{Number at risk}

\begin{tabular}{ll}
\hline No AKI 117 \\
\hline
\end{tabular}

\begin{tabular}{l|l} 
Stage $1 \quad 102$
\end{tabular}

\begin{tabular}{l|l|} 
Stage 2 & 71
\end{tabular}

Stage $3 \quad 86$

\begin{tabular}{|l|l|}
\hline 7 & 107 \\
\hline
\end{tabular}

88

66

77

\begin{tabular}{|l|l|l|l|l|}
\hline 79 & 98 & 81 & 59 & 41 \\
\hline 78 & 49 & 27 & 19 \\
\hline 6 & 60 & 45 & 25 & 15 \\
\hline 7 & 72 & 49 & 32 & 21 \\
\hline
\end{tabular}

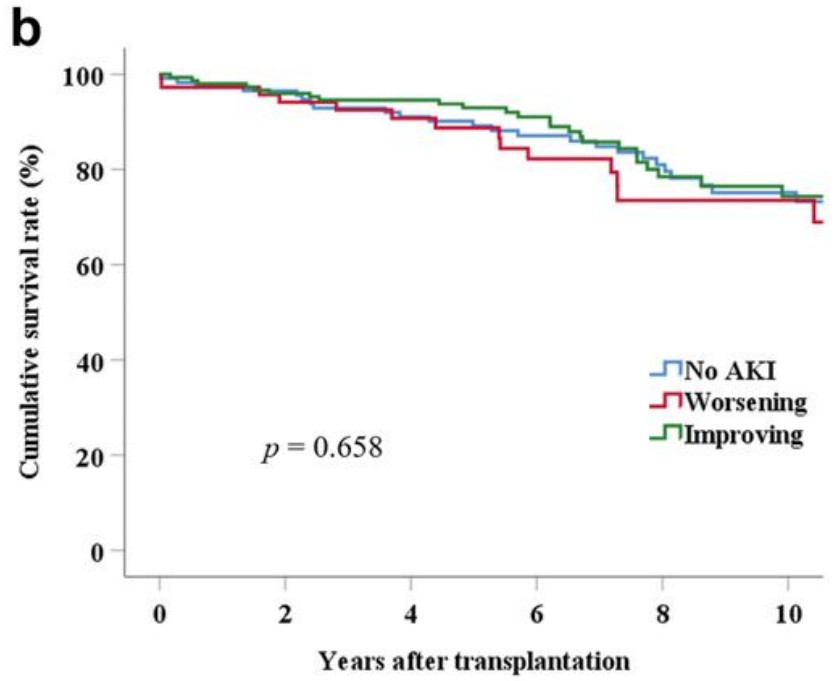

Number at risk

\begin{tabular}{|l|l|l|l|l|l|l|}
\hline No AKI & 117 & 107 & 98 & 81 & 59 & 41 \\
\hline Worsening & 73 & 60 & 49 & 37 & 25 & 16 \\
\hline Improving & 151 & 140 & 131 & 92 & 49 & 34 \\
\hline
\end{tabular}


Figure 2

Death-censored graft survival stratified by AKI severity and trend. (a) Death-censored graft survival stratified by AKI severity. Group comparisons were performed using the Kaplan-Meier and log-rank tests. (b) Death-censored graft survival stratified by the AKI trend. Group comparisons were performed using the Kaplan-Meier and log-rank tests.

a

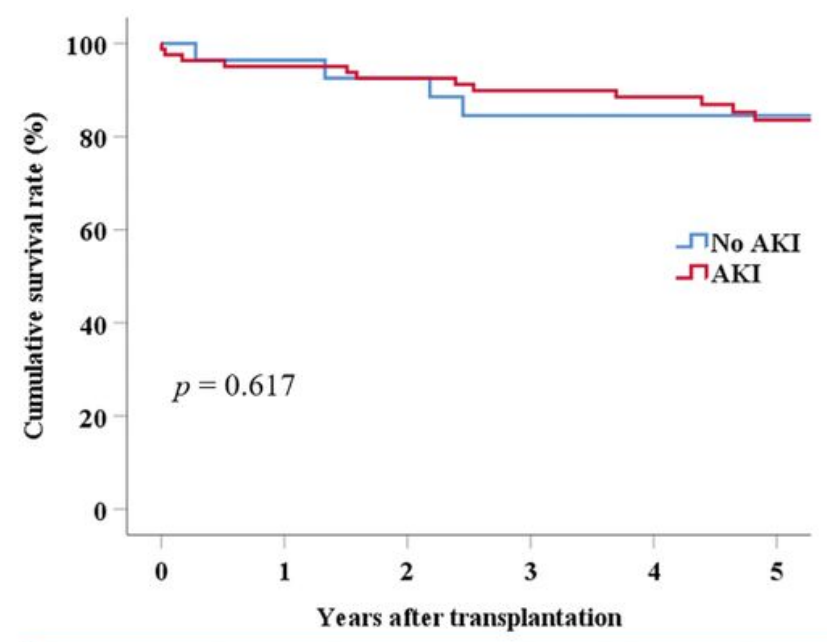

\section{Number at risk}

\begin{tabular}{|l|l|l|l|l|l|l|}
\hline No AKI & 28 & 25 & 23 & 21 & 19 & 16 \\
\hline
\end{tabular}

AKI $\quad 83$

\begin{tabular}{|l|l|l|l|l|}
\hline 75 & 71 & 66 & 63 & 45
\end{tabular}

\section{Figure 3}

Death-censored graft survival in recipients receiving kidneys from ECD and high KDPI $(\geq 80)$ donors stratified by the presence of AKI. (a) Death-censored graft survival in recipients receiving kidneys from ECDs stratified by the presence of AKI. Group comparisons were performed using the Kaplan-Meier and log-rank tests. (b) Death-censored graft survival in recipients receiving kidneys from high KDPI $(\geq 80)$ donors stratified by the presence of AKI. Group comparisons were performed using the Kaplan-Meier and log-rank tests. ECD, expanded criteria donor; KDPI, Kidney Donor Profile Index. 
a

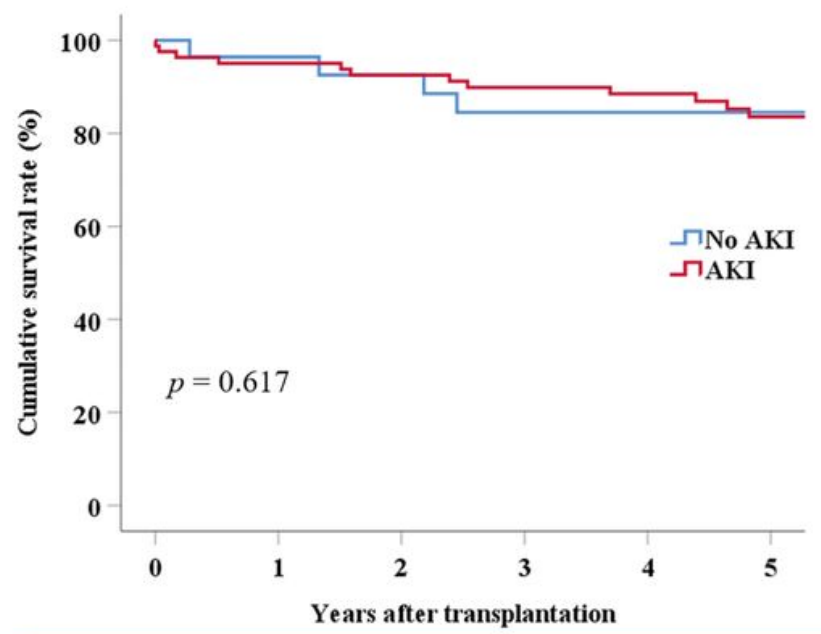

\begin{tabular}{|c|c|c|c|c|c|c|}
\hline \\
\hline \multicolumn{6}{|c|}{\begin{tabular}{l|l} 
Number at risk \\
No $A K I$ & 28
\end{tabular}} & \\
\hline AKI & 83 & 75 & 71 & 66 & 63 & 45 \\
\hline
\end{tabular}

b

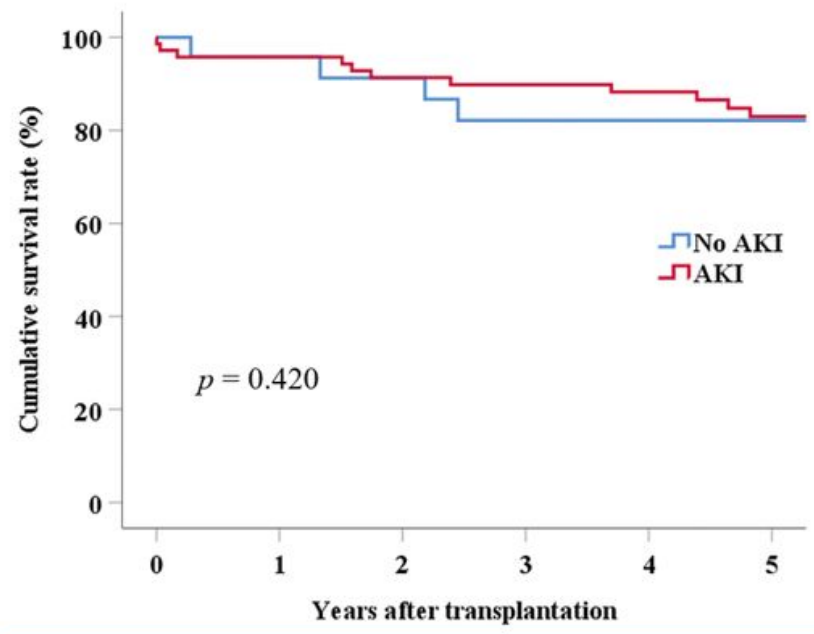

Number at risk

\begin{tabular}{|l|l|l|l|l|l|l|}
\hline No AKI & 24 & 22 & 20 & 18 & 16 & 13 \\
\hline
\end{tabular}

\section{Figure 3}

Death-censored graft survival in recipients receiving kidneys from ECD and high KDPI ( $\geq 80)$ donors stratified by the presence of AKI. (a) Death-censored graft survival in recipients receiving kidneys from ECDs stratified by the presence of AKI. Group comparisons were performed using the Kaplan-Meier and log-rank tests. (b) Death-censored graft survival in recipients receiving kidneys from high KDPI $(\geq 80)$ donors stratified by the presence of AKI. Group comparisons were performed using the Kaplan-Meier and log-rank tests. ECD, expanded criteria donor; KDPI, Kidney Donor Profile Index.
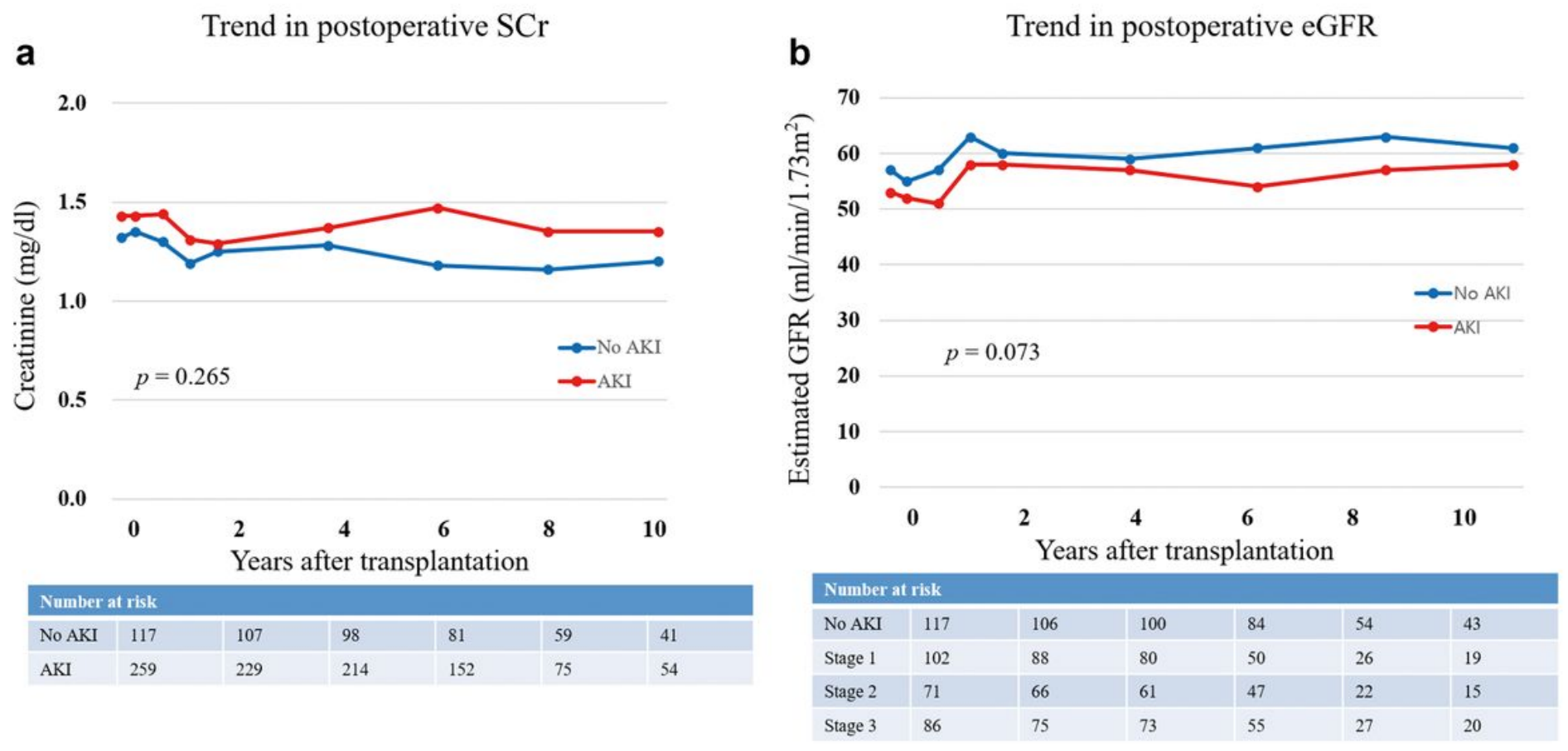
Trend in postoperative SCr and eGFR between the No AKI and AKI groups. (a) Trend in postoperative SCr stratified by the presence of AKI. Group comparisons were performed using a linear mixed model. (b) Trend in postoperative creatinine stratified by the presence of AKI. Group comparisons were performed using a linear mixed model. SCr, serum creatinine; eGFR, estimated glomerular filtration rate.
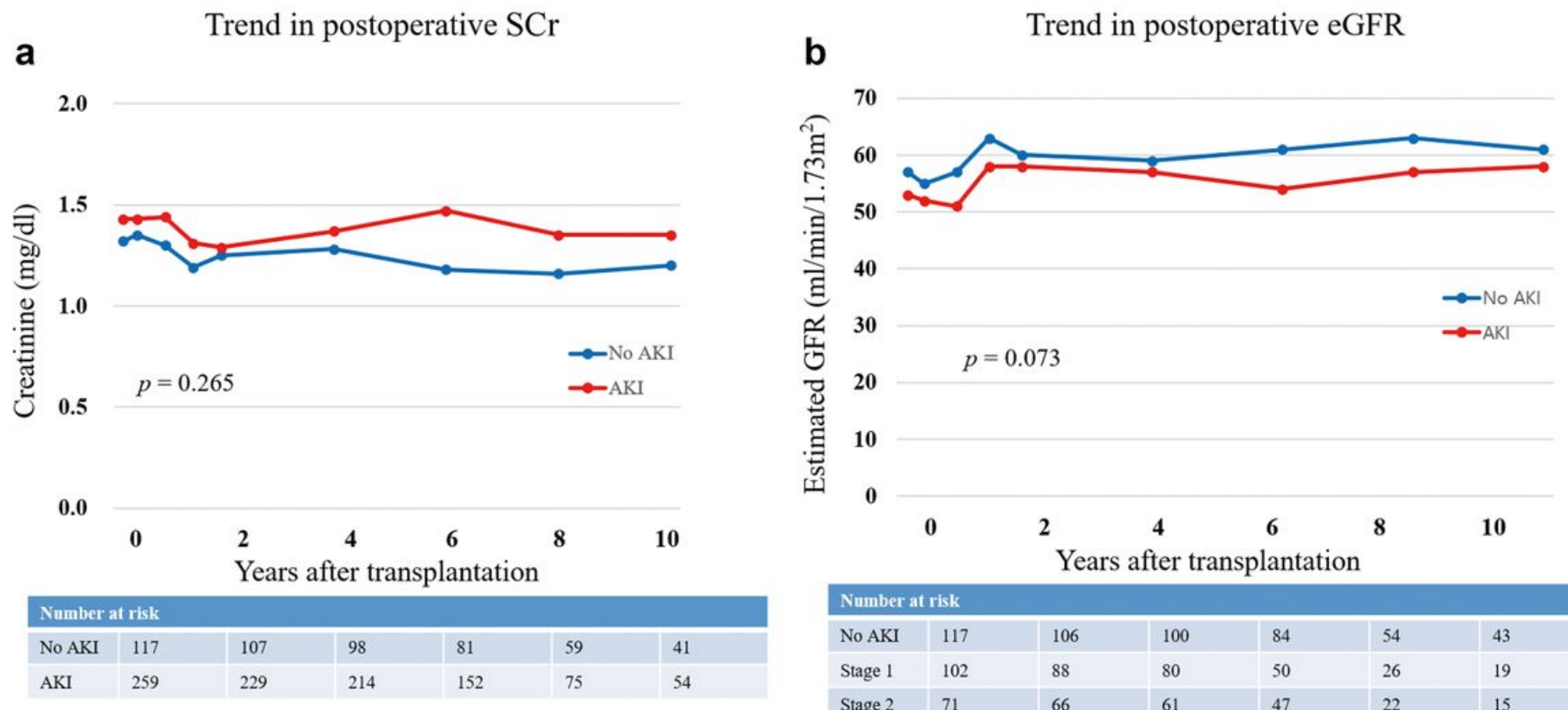

\begin{tabular}{|l|l|l|l|l|l|l|}
\hline \multicolumn{2}{|l|}{ Number at risk } & \multicolumn{10}{|c|}{ (106 } & 100 & 84 & 54 & 43 \\
\hline No AKI & 117 & 88 & 80 & 50 & 26 & 19 \\
\hline Stage 1 & 102 & 66 & 61 & 47 & 22 & 15 \\
\hline Stage 2 & 71 & 75 & 73 & 55 & 27 & 20 \\
\hline Stage 3 & 86 & & & & & \\
\hline
\end{tabular}

\section{Figure 4}

Trend in postoperative SCr and eGFR between the No AKI and AKI groups. (a) Trend in postoperative SCr stratified by the presence of AKI. Group comparisons were performed using a linear mixed model. (b) Trend in postoperative creatinine stratified by the presence of AKI. Group comparisons were performed using a linear mixed model. SCr, serum creatinine; eGFR, estimated glomerular filtration rate. 
554 patients

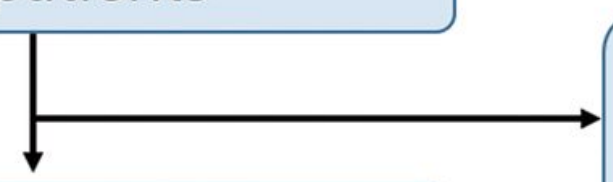

527 patients $\mathrm{SCD} / \mathrm{ECD}$

\section{5 patients Primary KT/Single organ}

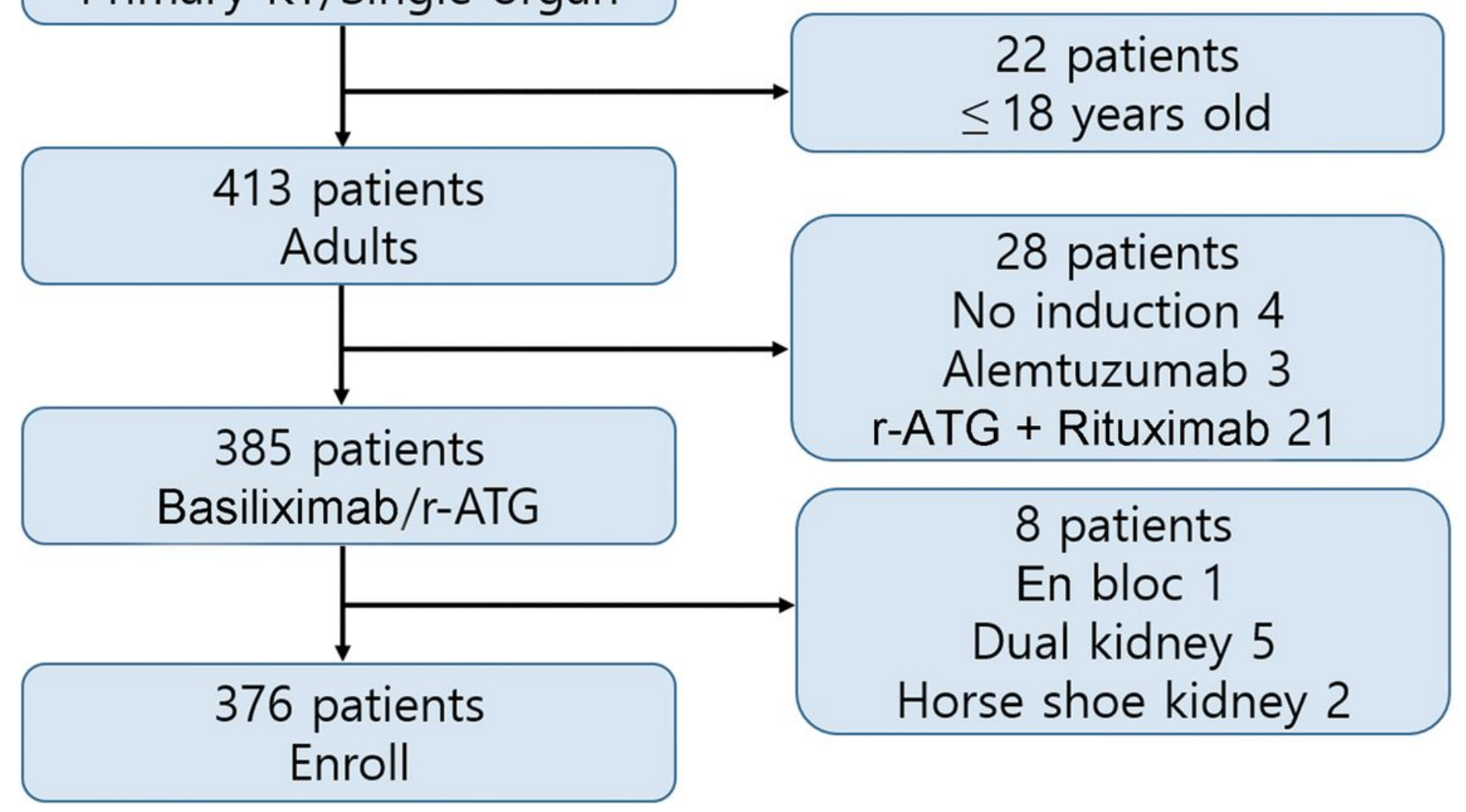

Figure 5

Flow chart of the patient selection process. SCD, standard criteria donor; ECD, expanded criteria donor; DCD, donation after circulatory death; KT, kidney transplantation; r-ATG, rabbit anti-thymocyte globulin. 
554 patients

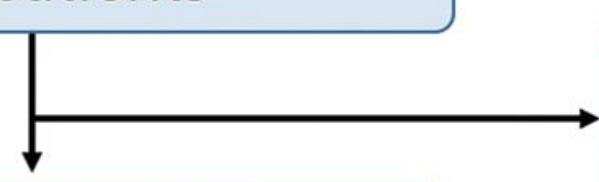

527 patients SCD/ECD

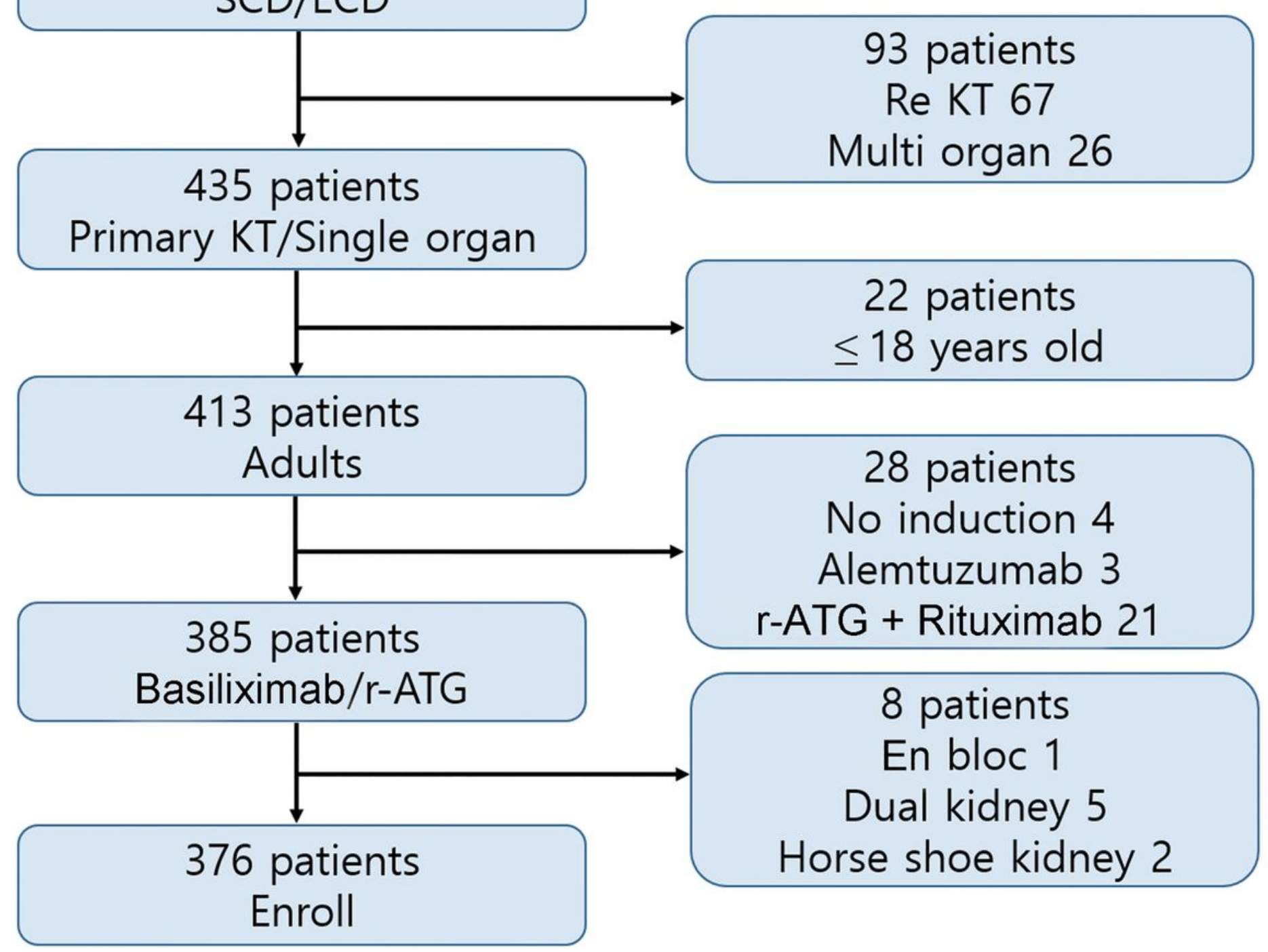

Figure 5

Flow chart of the patient selection process. SCD, standard criteria donor; ECD, expanded criteria donor; DCD, donation after circulatory death; KT, kidney transplantation; r-ATG, rabbit anti-thymocyte globulin.

\section{Supplementary Files}

This is a list of supplementary files associated with this preprint. Click to download. 
- SupplementaryMaterial.docx

- SupplementaryMaterial.docx 